\title{
DISABLING THE ADA: ESSENCES, BETTER ANGELS, AND UNPRINCIPLED NEUTRALITY CLAIMS
}

\author{
AVIAM SOIFER*
}

"Thou shalt not curse the deaf, nor put a stumbling-block before the blind ...."

The current Supreme Court delights in proclaiming devotion to matters the Justices define as "essential." As with other kinds of fundamentalism, the crucial question tends to be where one starts. Presumptions also matter. Even judicial protection for the dignity of somebody or something may turn out to be key. ${ }^{2}$

* Professor of Law, Boston College Law School. I am grateful to the William and Mary School of Law and to my fellow participants for what turned out to be an unusually fruitful and enjoyable symposium. In particular, I thank Michael Stein for his exceptional hard work, imagination, enthusiasm, and assistance. This Article also benefitted greatly from the efforts of several research assistants, particularly Raushanah Daniels, Julio Portilla, and Dan Roth, as well as from Alice Lyons' customary invaluable help. Friends and colleagues Tom Baker, Freda Fisher, Linda Long, Allan Macurdy, Michael Stein, and Carol Weisbrod read drafts and helped save me from myself, at least somewhat. They contributed generously from their remarkable inventories of abilities, wisdom, and very limited time. Finally, the Law Review staff proved to be an unusually pleasant group of people with whom to work and their help with this Article is much appreciated.

1. Leviticus 19:14. "(B) ut thou shalt fear thy God: I am the Lordl,]" the Hebrew Bible continues. Id. One might think that it is not good to curse someone who can hear, or to put a stumbling block in front of anyone else. The "special treatment" suggested is underscored, and perhaps made still more paradoxical, by what follows. We next are told, "Ye shall do no unrighteousness in judgment; thou shalt not respect the person of the poor, nor favour the person of the mighty; but in righteousness shalt thou judge thy neighbour." THE PENTATEUCH AND HAFTORAHS 500-01 (J.H. Hertz ed., 2d ed. 1961). I began to explore this paradox, which is also a source for the language of the current federal judicial oath, in AVIAM SOIFER, LAW AND THE COMPANY WE KEEP 164-81 (1995).

2. The abstract concept of dignitary harms to the states has become a crucial benchmark, as the Court recently emphasized in Federal Maritime Commission v. South Carolina State Ports Authority, 122 S. Ct. 1864, 1874 (2002)(holding that state sovereign immunity precludes adjudication of a private party's claim against a nonconsenting state by federal agency, because " $[t]$ he preeminent purpose of state sovereign immunity is to accord States the dignity that is consistent with their status as sovereign entities"). That the dignity of people with disabilities counts for much less will become apparent in this Article. 
There is a tendency, of course, for the essences discovered by judges to overlap with what is decried as result-oriented judging. Yet the façade of judicial neutrality today seems unusually prone to enable activist judges to launch preemptive strikes against protective measures they dislike. Current judges claim to do this in the name of essential autonomy, but generally it is in the service of those in power. Indeed, we increasingly seem to function under the kind of Platonic Guardianship vehemently criticized in an earlier era. $^{3}$

Notwithstanding the current majority's frequent declarations of a clear, binary world full of essences, it is sobering to consider the incoherence in the Justices' statements about the adequate grounding, metes and bounds, and regular topography of public law. Concern for turf is a crucial judicial trope today. So is the Court's insistence on a series of Manichean choices that the Court alone may make. As this Article suggests, the way that sovereignty over the legal landscape is mapped-and even the question of whether the territory may be regulated at all by any government-is now a dominant constitutional motif reaching far beyond the realm of property disputes. It is now clear that a majority of the Justices often deny that there is or should be any middle ground -or, for that matter, any significant public law changes that are not instigated by the Justices themselves.

The current Supreme Court, for example, intercedes actively on behalf of essences it perceives in the realms of federalism, ${ }^{4}$ property

3. For example, Justice Black, dissenting in Griswold v. Connecticut, 381 U.S. 479 (1965), cited Learned Hand's well-known statement, "For myself it would be most irksome to be ruled by a bevy of Platonic Guardians, even if I knew how to choose them, which I assuredly do not." Id. at 526-27 (quoting LEARNED HAND, THE BILL OF RIGHTS 73 (1958)).

4. Within the Court's recent-and already noticeably lengthy-string of New Federalism decisions, for example, a narrow majority repeatedly has interposed its vision of some essence of dual sovereignty to invalidate contrary judgments by Congress and earlier Court majorities. See, e.g., Fed. Mar. Comm'n v. S.C. State Ports Auth., 122 S. Ct. 1864, 1871, 1879 n.18 (2002) (holding that principles of state sovereign immunity are not anchored in constitutional text but are "embedded in our constitutional structure" and "enshrined in our constitutional framework"); United States v. Morrison, 529 U.S. 598 (2000) (limiting the reach of the Commerce Clause); Garcia v. San Antonio Metro. Transit Auth., 469 U.S. 528, 581 (1985) (O'Connor, J., dissenting) ('The true 'essence' of federalism is that the States as States have legitimate interests which the National Government is bound to respect even though its laws are supreme.") (citing Younger v. Harris, 401 U.S. 37, 44 (1971)). 
rights, ${ }^{5}$ and even Roe $v$. Wade. ${ }^{6}$ Sadly, this judicial phenomenon is hardly limited to constitutional law. Judicial authoritarianism also abounds in the name of statutory interpretation.

The Court's recent deconstruction of the Americans with Disabilities Act (ADA) provides a series of striking illustrations. In the name of essences that the Justices alone can discern, the Court repeatedly ignores or overrules Congress. It also rejects interpretations painstakingly worked out by lower court judges. ${ }^{7}$ The Court has turned an important civil rights statute into an unseemly hash. Little noted and not remembered is the spirit at the time of

5. See, e.g., Dolan v. City of Tigard, 512 U.S. 374 (1994) (requiring essential nexus between legitimate state interests and permit condition); Lucas v. S.C. Coastal Council, 505 U.S. 1003 (1992) (identifying the notion of "essential use" of land); Hodel v. Irving, 481 U.S. 704 (1987) (regarding as a taking the abrogation of the right of individual Indian tribal members to pass on property via descent and device, similar to essential right of owner to exclude from property). At a minimum, the essentialist drive in the realm of regulatory takings was slowed down by Tahoe-Sierra Preservation Council, Inc. v. Tahoe Regional Planning Agency, 122 S. Ct. 1465 (2002). In fact, there is no plausible textualist argument to support the Court's recent aggressive expansion of the regulatory takings doctrine led by Justice Scalia. A deep problem in text, history, and logic remains because after the Fifth Amendment offers the protection against deprivation of "life, liberty, or property, without due process of law," it continues, "nor shall private property be taken for public use, without just compensation." U.S. CONST. amend. V. The Fourteenth Amendment repeats the due process formulation, of course, but it then omits the next clause. U.S. CONST. amend. XIV. Thus somersaults are necessary —and not even attempted by the Court-to claim that the Framers of the Fourteenth Amendment intended to incorporate a specific guarantee of just compensation when that very protection was stated in the Fifth Amendment text they copied, but strikingly omitted from the new Fourteenth Amendment.

6. 410 U.S. 113 (1973). In a well-known statement regarding stare decisis by Justices O'Connor, Kennedy, and Souter in Planned Parenthood of Southeastern Pennsyluania $v$. Casey, 505 U.S. 833 (1992), the three found it "imperative to adhere to the essence of Roe's original decision ...." Id. at 869 . Their joint opinion insisted that "to overrule Roe's essential holding" would entail no less than "the cost of both profound and unnecessary damage to the Court's legitimacy, and to the Nation's commitment to the rule of law." Id. at 836. There has been considerable debate as to whether the troika did indeed preserve some essence, or instead left standing only what Chief Justice Rehnquist's dissent called "a sort of judicial Potemkin Village ...." Id. at 966.

7. It is striking that this Court, whose docket has shrunk significantly in recent years, continues to take and decide many ADA cases. During the $2001 \mathrm{Term}$, in which the Court handed down only eighty-three full decisions, four decisions directly involved the ADA. In all four, the Court reversed the decisions of the courts of appeals. As will be discussed below, in Toyota Motor Manufacturing v. Williams, 534 U.S. 184 (2002) and Cheuron U.S.A., Inc. v. Echazabal, 122 S. Ct. 2045 (2002), the Court was unanimous. In Barnes v. Gorman, 122 S. Ct. 2097 (2002), there was a somewhat bitter division as to the appropriate basis for the decision, but all the Justices again agreed on the result. In US Airways v. Barnett, $122 \mathrm{~S}$. Ct. 1516 (2002), however, the Court could hardly have been more splintered. 
the ADA's passage, when President George H.W. Bush hailed the new law as "an historic opportunity. It signals the end to the unjustified segregation and exclusion of persons with disabilities from the mainstream of American life." As we shall soon see, the ADA, as construed by the current Court, can hardly be said to do much of anything to protect people with disabilities. Instead the Court's activist interventionism has done a great deal to shield both private employers and public officials, in addition to denying the importance of past discrimination while preserving as much of the pre-ADA status quo as possible. The Court's central message to people with disabilities seems to be, "Get over it."

Plato may have advocated a search for abstract pure essences, but his student, Aristotle, suggested that such a quest must be premised on engagement with concrete cases. ${ }^{9}$ The current Court's restrictive view of the $\mathrm{ADA}$ seems to be virtually the stultifying obverse of the Court's broad, case-by-case interpretation of the Civil Rights Act of 1964. But that earlier, permissive approach to civil rights guarantees-much more in keeping with the ADA's words, findings, and clear intentions-remains viable; occasionally, it can even be discerned peeping out from under the current Court's work product. In the current Supreme Court, however, there are simply not enough votes to sustain a significant countertrend.

Nonetheless, a different, better legal approach should not be allowed to disappear under the mound of the Court's recent technical-seeming, yet actually sweeping, interpretations of the ADA. Such a different approach entails critical attention to starting places. This approach is more concerned with human dignity than with the dignity of the states, though it recognizes that both often can be protected simultaneously. It also heeds some of the traditional demands of judicial craftsmanship. In construing a statute such as the ADA, for example, such an interpretation seeks to understand what problems Congress targeted and what Congress actually said and did.

8. Statement of President George Bush, 26 WEekLY COMP. PRES. DOC. 1166 (July 26, 1990). That the first Bush administration was not entirely consistent about the ADA, however, is made clear in Allan Macurdy, The Americans with Disabilities Act of 1990: A Time for Celebration or A Time for Caution?, 1 B.U. PUB. INT'L L.J. 21 (1991).

9. See ARISTOTLE, METAPHYSICS Book VII (Montgomery Furth trans., 1985). 
During the Court's 2000 Term, two major ADA decisions starkly illuminated basic assumptions by the Justices concerning statutory language, default positions, and the appropriate weight to be accorded change. Board of Trustees of the University of Alabama $v$. Garrett ${ }^{10}$ and PGA Tour, Inc. v. Martin ${ }^{11}$ also highlighted a possible alternative approach, in which seemingly inconsistent views of the legal claims of people with disabilities might be reconciled. By pursuing the intersection of essences and accommodation, of legitimate starting points and acceptable changes in Part I, we learn a good deal about what treating like cases alike currently means, as well as what the concept ought to entail if we take the ADA seriously. A statutory regimen that purports to protect the full and equal rights of those of us who are not entirely able to compete equally with fellow citizens in all aspects of life underscores deep dilemmas of capability and paternalism. Concrete consideration of the ADA's alternative possibilities, however, also emphasizes both the Court's sloppiness and its own transgressions of the limits of the law.

This Article begins with a brief review of the Court's extraordinarily cramped view of Congress' constitutional power in Garrett. That decision, holding that Congress could not constitutionally include employment discrimination practiced by states within the range of the individual damage remedies mandated by the $\mathrm{ADA},{ }^{12}$ is already having substantial repercussions. Moreover, the purported constitutional underpinning for Chief Justice Rehnquist's majority opinion turns out to be both very recent and very shaky.

At first glance, a concurring opinion in Garrett, written by Justice Kennedy and joined by Justice O'Connor, might seem to offer some hope. Upon closer examination, however, this decisive concurrence reveals a stark lack of both self-awareness and empathy, conjoined with a failure of the judicial imagination; in the name of preserving the purported neutrality of states that discriminate in employment.

Part II considers Martin, and the Court's surprising seven-to-two vote upholding application of the ADA's public accommodation

10. 531 U.S. 356 (2001).

11. 532 U.S. 661 (2001).

12. Garrett, 531 U.S. at 366-67. 
provision, thus allowing a competitive player on the professional golf tour to use a golf cart during tournament play. ${ }^{13}$ A brief comparison of this victory for the ADA with other recent decisions about public accommodations helps explain why the Martin dissenters-Justice Scalia and Justice Thomas-were so upset. Casey Martin won an important victory, but it is most likely to be largely symbolic. In fact, when we compare Martin to the Garrett decision, we may begin to suspect a stealth strategy on the part of the swing voters on the Court. The swing Justices will accept narrow instances of ADA coverage that are likely to grab public attention and are easily restricted to their unusual facts. Yet a majority remains firmly unconvinced that millions of people with disabilities need substantial legal protection in the major activities of life-or the Justices may believe that those who are disabled may not constitutionally be permitted to receive such protection from the federal government.

Part III discusses some significant implications of the general view of disability that emerges from the Court's most recent decisions. If disability cases serve as a kind of Rorschach test, then it is striking just how revealing this test can be. Even brief comparison with several recent appellate court decisions underscores the incoherence of the Court's either/or, and only purportedly individualized, approach to disability issues.

Part IV dares to reenter the nearly impenetrable definitional tangle that has resulted from the Court's aggressive reluctance to accept the ADA on its own terms. ${ }^{14}$ It focuses on the Court's four decisions construing the ADA during the 2001 Term. The inconsistency and even incoherence in the Court's approach is most clearly discerned by looking closely at Toyota Motor Manufacturing $v$. Williams. ${ }^{15}$ But this Part also briefly considers the paternalism

13. Martin, 532 U.S. at 661.

14. It is noteworthy that the Court continues to choose to take so many ADA cases, particularly at a time when it is taking many fewer cases than did its predecessor Courts not many years ago. See supra note 7. See generally Margaret M. Cordray \& Richard Cordray, The Supreme Court's Plenary Docket, 58 WASH. \& LEE L. REV. 737 (2001) (providing both empirical and nonempirical analysis of the declining size of the Court's plenary docket). For a discussion of the Court's earlier ADA decisions, see Aviam Soifer, The Disability Term: Dignity, Default, and Negative Capability, 47 UCLA L. REv. 1279 (2000).

15. 534 U.S. 184 (2002). 
found acceptable by a unanimous Court in Echazabal; the very narrow survival of an employment discrimination claim when Barnett confronts an employer-imposed seniority system; ${ }^{16}$ and the Gorman ${ }^{17}$ Court's willingness to protect defendants from punitive damage awards anchored in successful ADA claims.

Finally, this Article briefly sketches the implications of an alternative approach. To illustrate, it juxtaposes the basic concept of public accommodations with the case-by-case "reasonable accommodation" requirement of the ADA. By statute, public accommodations must afford full, as well as equal, "enjoyment of the goods, services, facilities, privileges, advantages, or accommodations of any place of public accommodation ...." ${ }^{n 18}$ This section suggests the importance of protection as well as equality; of alterations, renovations, and progress as well as historic preservation; and of recognizing the fundamental values of a living tradition rather than struggling to remain confined to some imagined, frozen past. By reconsidering what the Justices recently have said about our heads and hearts - and even about how we constitute "us" and "them" in the disability context-we may discover a better, more direct, and more ecologically sound path across the entangled, rocky underbrush of current disability law.

I. Positive LAW, EQUAL PROTECTION, AND OUR BetTer ANGELS: BOARD OF TRUSTEES OF THE UNIVERSITY OF ALABAMA V. GARRETT ${ }^{19}$

\section{A. Hardheaded-and Even Hardhearted-States}

\section{Equal Protection v. Positive Law}

At first reading, Chief Justice Rehnquist's majority opinion in Garrett may seem simply a predictable extension of what the Court's

16. US Airways v. Barnett, 122 S. Ct. 1516 (2002).

17. Barnes v. Gorman, 122 S. Ct. 2097 (2002).

18. 42 U.S.C. $\$ 12182(a)(2000)$. As the Court elaborated in Martin, "The phrase public accommodation' is defined in terms of 12 extensive categories, which the legislative history indicates 'should be construed liberally' to afford people with disabilities 'equal access' to the wide variety of establishments available to the nondisabled." 532 U.S. at 676-77 (footnotes omitted).

19. 531 U.S. 356 (2001). 
vigorous activism in the name of federalism recently has wrought. The Court held that the enforcement power granted to Congress through Section Five of the Fourteenth Amendment does not extend to using the ADA to protect people with disabilities from employment discrimination perpetrated by states. ${ }^{20}$ But Chief Justice Rehnquist actually managed to go even further in rejecting the results of democratic processes than the Court previously had done in its recent explosion of New Federalism decisions.$^{21}$ Indeed, Garrett illustrates that the current Court has devised an entirely new series of steps to divide and conquer congressional power. ${ }^{22}$ Three of the Court's moves were breathtaking.

First, the Court switched the burden to prove constitutionality to anyone who seeks to vindicate congressional power-and made it a heavy burden at that. Rehnquist stated that the first step is to seek precise identification of the constitutional right at stake. ${ }^{23}$ Apparently only one source occurred to the Court in defining that constitutional right, City of Cleburne v. Cleburne Living Center, Inc. ${ }^{24}$ Because the Cleburne Court purported to apply only permissive lower tier "rational relationship" scrutiny to a discrimination claim based on the disabilities of residents of a group home, it follows, said Rehnquist, that Congress may go no further ${ }^{25}$ But actually Rehnquist read Cleburne exclusively in terms of its dictum. Even in doing this, Rehnquist compounded a bitter irony. He failed to notice that a specific reason Cleburne Court gave for not applying heightened scrutiny on behalf of the mentally retarded

20. Id. at 374.

21. For a somewhat lengthier discussion of Garrett within the New Federalism context, see Aviam Soifer, Courting Anarchy, 82 B.U. L. REv. 699 (2002).

22. This is reminiscent of what the Court did to eviscerate Reconstruction. See generally Charles L. Black, JR., A NeW BIRTH OF Freedom 41-85 (1997) (discussing the Slaughterhouse Cases and other cases that severely limited the meaning and application of the Civil War Amendments); Aviam Soifer, Status, Contract, and Promises Unkept, 96 Yale L.J. 1916 (1987).

23. Garrett, 531 U.S. at 365.

24. 473 U.S. 432 (1985) (applying "rational relation" test to determine the constitutionality of a zoning ordinance prohibiting "hospital[s] for the feeble minded"). But see Heller v. Doe, 509 U.S. 312 (1993) (upholding a Kentucky law establishing disparate burdens of proof for committing "mentally retarded" and "mentally ill" individuals); Buck v. Bell, 274 U.S. 200, 207 (1927) (upholding a Virginia statute entailing mandatory sterilization for mentally disabled women).

25. Garrett, 531 U.S. at 368. 
plaintiffs in the case was that a positive legislative response, "which could hardly have occurred and survived without public support, negates any claim that the mentally retarded are politically powerless in the sense that they have no ability to attract the attention of the lawmakers. ${ }^{26}$ Garrett, paradoxically, invalidated the very type of legislative victory the Cleburne majority relied upon in deciding that persons with disabilities do not require heightened judicial solicitude. To compound the irony even more, however, Rehnquist blatantly ignored what the Court actually did in Cleburne. That the disabled plaintiffs won the case in Cleburne was nowhere mentioned in Garrett. Such selective misreading of a case's holding ought to embarrass a first-year law student.

In Cleburne, the Court in fact carefully examined and rejected a series of purported reasons offered by government officials in defense of their official actions against mentally retarded people. Justice White's lead opinion specifically noted that the link between a claimed governmental rationale and any purported end sought by the government could not be so attenuated as to be arbitrary; he also insisted that the bare desire to harm a politically unpopular group is constitutionally illegitimate. ${ }^{27}$ Yet, White added, constitutional protection must stretch further. He explained, "Beyond that, the mentally retarded, like others have and retain their substantive constitutional rights in addition to the right to be treated equally by the law. ${ }^{28}$ Looked at with care, the Court found that the actions of the government officials seemed anchored in "irrational prejudices" and thus were invalid. It should be noted -particularly in light of Rehnquist's treatment of Cleburne as if it were an extremely deferential, low-tier equal protection case akin to a challenge to an economic regulation - that a majority of the Justices endorsed more aggressive equal protection scrutiny than White's opinion applied in Cleburne. ${ }^{29}$ Yet even White's opinion was

26. Cleburne, 473 U.S. at 445 .

27. Id. at 447.

28. Id. By suggesting that mentally retarded people retain substantive rights, such as freedom of association, as well as equality rights, the Court echoed distinct prongs of the famous footnote four in United States v. Carolene Products Co., 304 U.S. 144, 153 n.4 (1937).

29. Rehnquist, who joined White's Cleburne opinion, might have remembered that Justice Stevens, along with Chief Justice Burger, also joined White's opinion but added a separate concurrence advocating a continuum for equal protection analysis, rather than the three tiers 
anything but deferential as it scrutinized with care and then struck down governmental discrimination against people with disabilities.

Rehnquist's next step was to hold that workplace practices that unquestionably constitute employment discrimination against persons with disabilities, when practiced by states, are likely to be economically rational-and thus entirely beyond the reach of constitutional law. ${ }^{30}$ To get to this shocking point, Rehnquist first observed, "States are not required by the Fourteenth Amendment to make special accommodations for the disabled, so long as their actions toward such individuals are rational. ${ }^{\text {n1 }} \mathrm{He}$ then asserted, "They could quite hardheadedly - and perhaps hardheartedly-hold to job-qualification requirements which do not make allowance for the disabled. ${ }^{\mathbf{n 2}}$

In case we missed it, toward the end of his majority opinion, Rehnquist offered a reprise of his embrace of admittedly discriminatory conduct. He explained the unconstitutional burden that an overreaching Congress imposed through the ADA as follows: "[W]hereas it would be entirely rational (and therefore constitutional) for a state employer to conserve scarce financial resources by hiring employees who are able to use existing facilities, the ADA requires employers to 'mak[e] existing facilities used by employees readily accessible to and usable by individuals with disabilities. ${ }^{\text {m33 }}$ Stripped to its basics, the Court perceived a stark conflict. The rationality of economic maximizing along with states' rights must prevail over Congress' efforts to prevent discrimination.

generally favored by the Court. Stevens likened the situation of people with disabilities to classifications of people based on gender, alienage, and illegitimacy. This connection was, Stevens explained, "because the characteristics of these groups are sometimes irrelevant to a valid public purpose, or, more specifically, to the purpose that the challenged laws purportedly intended to serve." Cleburne, 473 U.S. at 453 . He called for "especially vigilant" judicial scrutiny of government classifications that deal with groups whose members face a "tradition of disfavor." Id. at 453 n.6. Justice Marshall, joined by Justices Brennan and Blackmun, concurred in part in the judgment and dissented in part. The Marshall trio forcefully advocated a higher level of judicial scrutiny in cases that involve disability classifications.

30. Garrett, 531 U.S. at 369-72.

31. Id. at 367.

32. Id. at 367-68.

33. Id. at 372 (citing 42 U.S.C. $\S 12112(\mathrm{~b})(5)(B), 812111(9)(2000)$ ). 
Garrett establishes a triumphant syllogism:

(1) It is rational for states to save money by refusing to make any allowances for the disabled.

(2) The Court's equal protection analysis will accept any rational basis for state classifications-including classifications that admittedly discriminate-even if Therefore, they inarguably and directly hurt disabled people.

(3) Congress may not use its enforcement powers to reach employment discrimination practiced by states.

Under Garrett, Congress is constitutionally disabled from enacting legislation that affirmatively seeks to guarantee constitutional rights through the enforcement clauses of the Reconstruction Amendments. The post-Civil War amendments are said to be limited starkly to matters of negative liberty. ${ }^{34}$ The Court thus has arrogated for itself untethered authority to engage in second-guessing Congress.

It is particularly galling that the majority seized this sweeping discretionary authority in the name of determining "the metes and bounds of the constitutional right in question," after which "we examine whether Congress identified a history and pattern of unconstitutional employment discrimination by the States against the disabled. ${ }^{35}$ But the final infuriating move was the way the Court determined that Congress did not sufficiently identify such a history and pattern.

The Garrett majority resorted to a Fractured Fairy Tale approach, reminiscent of Goldilocks' methodology, when it turned to the extensive findings and record assembled by Congress in support of the ADA. If Congress noted too many examples, as in the Violence Against Women Act ${ }^{36}$ struck down in United States v. Morrison, ${ }^{37}$ the legislation would be unconstitutional because it was too sweeping; if Congress found too few incidents, however, the record

34. See, e.g., DeShaney v. Winnebago County Dep't. of Soc. Servs., 489 U.S. 189 (1989).

35. Garrett, 531 U.S. at 368.

36. 42 U.S.C. $\$ 13981(2000)$.

37. 529 U.S. 598, 626-27 (2000) (concluding that Congress lacked constitutional authority under the Commerce Clause to enact the remedy in $\$ 13981$ ). 
turned out to be anecdotal, and therefore constitutionally inadequate. ${ }^{38}$ What might be just right remains a secret, apparently entirely a matter of what porridge the Justices want for breakfast.

Sometimes the Court almost playfully knocks clusters of congressional findings entirely out of consideration just before assessing whether the congressional findings will suffice. In Garrett, for example, in the course of addressing the extensive record of numerous discriminatory acts perpetrated by state and local governments as duly noted by Congress, the Court used a grand non sequitur to wipe all local government examples from consideration. Discriminatory acts by local entities-normally actionable under 42 U.S.C. \& 1983 - simply disappeared on the grounds that the Eleventh Amendment has been held to shield states, but not their subdivisions. The Court thus transformed all of Congress' factfinding about discriminatory practices by cities, towns, counties, and other localities into nothingness. ${ }^{39}$ Of course, those who worked hard to pass the ADA in 1990 had no way of knowing that the Court's subsequent expansion of states' rights barriers-as a direct limit on Congress' enforcement power-would have fatal repercussions for congressional fact-finding completed years earlier.

Most of all, the Garrett majority condemned constitutional duties imposed on the states. The Fourteenth Amendment is often read as an attempt to require states to do things. As Rehnquist stated for the Court, however, "[i]f special accommodations for the disabled are to be required, they have to come from positive law and not through the Equal Protection Clause. ${ }^{\mathbf{4 0}}$ Prior to Garrett, would anyone have thought that the Equal Protection Clause is somehow distinct from and apparently less than positive law?

Startling as this notion may be, it is consistent within the Chief Justice's dichotomous world view. States' rights severely limit or even eliminate federal authority to enact "positive law." Under

38. City of Boerne v. Flores, 521 U.S. 507, 630-31 (1997) (holding religious Freedom Restoration Act unconstitutional because, in contrast to Voting Rights Act of 1965, legislative record lacked modern examples adequate to support congruence and proportionality of congressional action).

39. As we will see when we consider Barnes v. Gorman, 122 S. Ct. 2097 (2002), the Court also has found sweepingly restrictive means of statutory interpretation to limit the effectiveness of litigation by individuals deprived of their civil rights. See infra note 197 and accompanying text.

40. Garrett, 531 U.S. at 368. 
Garrett, every state's understandable and even commendable desire to "conserve scarce financial resources"1 becomes a trump. Moreover, Congress confronts an iron triangle if it seeks to establish the kind of factual predicate the Court now requires for any forward-looking efforts to combat discrimination. ${ }^{42}$ Neither statistics nor anecdotes will do. Further, it certainly is not constitutionally permissible for the dignity of the states to suffer harm.

2. "Our Own Human Instincts," "The Better Angels of Our Nature," and "Those Disadvantaged by Mental or Physical Impairments ${ }^{\text {mas }}$

If the Garrett majority opinion ended on a discordant positive law note, Justice Kennedy's concurrence, joined by Justice O'Connor, began on a genuinely positive note. Suggesting that progress is possible, Justice Kennedy offered an important insight: "Prejudice, we are beginning to understand, rises not from malice or hostile animus alone. ${ }^{n 46}$ In fact, Kennedy added, "[Prejudice] may result as well from insensitivity caused by simple want of careful, rational reflection or from some instinctive mechanism to guard against people who appear to be different in some respects from ourselves. ${ }^{\mathbf{m 7}}$

Yet after this significant opening, Kennedy quickly moved to identify a great struggle between "our own human instincts" ${ }^{\text {p8 }}$ (that unsettle us when we encounter people who seem different), on the one hand, and "the better angels of our nature, ${ }^{n 49}$ on the other.

While our baser human instincts and better angels must wrestle each other, Kennedy seemed to make his own preference clear. He stated his admiration for the ADA, for example, describing it as "a milestone on the path to a more decent, tolerant, progressive

41. Id. at 372 .

42. For a discussion of the unreal Goldilocks quality of what the Court's new constitutional demands in support of congressional action are, see Soifer, supra note 21, at 712-13.

43. Garrett, 531 U.S. at 375 (Kennedy, J., concurring).

44. Id. (Kennedy, J., concurring).

45. Id. at 376 (Kennedy, J., concurring).

46. Id. at 374 (Kennedy, J., concurring).

47. Id. (Kennedy, J., concurring).

48. Id. at 375 (Kennedy, J., concurring).

49. Id. (Kennedy, J., concurring). 
society. ${ }^{n 50}$ Perhaps echoing Brandeis' famous Olmstead v. United States $^{51}$ dissent, Kennedy also emphasized that "law can be a teacher ${ }^{\mathrm{n2} 2}$ and that the lessons law can teach may be significant. Indeed, he added sweepingly that "[o]ne of the undoubted achievements of statutes designed to assist those with impairments is that citizens have an incentive, flowing from a legal duty, to develop a better understanding, a more decent perspective, for accepting persons with impairments or disabilities into the larger society." ${ }^{\text {"63 }}$ But there is a fatal flaw, perhaps some version of original sin. We cannot live in a happy world of citizens learning from the law while progress is made. The Constitution demands invalidation. Why?

The explanation was anchored in Kennedy's insistence on reifying sovereignty. He was explicit on this point, describing the states as "neutral entities, ready to take instruction and to enact laws when their citizens so demand. ${ }^{m 54}$ Elsewhere, Kennedy famously celebrated the genius of the Framers in their ability to "split the atom of sovereignty, ${ }^{255}$ but in Garrett he could see only neutral states that are limited to taking instruction from their own demanding state citizens. There may not be a federal legislative teacher. No middle ground can be found.

The only exception is if a stringent precondition is met. There must be "confirming judicial documentation," Kennedy maintained, because "purposeful and intentional action [is] required to make out a violation of the Equal Protection Clause. ${ }^{n 56}$ Only judges are

50. Id. (Kennedy, J., concurring).

51. 277 U.S. 438 (1928).

52. Garrett, 531 U.S. at 375. Dissenting in Olmstead, Justice Brandeis emphasized the crucial role the government plays as a teacher, and he tied this point to his view that lawlessness by government officials ought not to go unsanctioned. Olmstead, 277 U.S. at 485 (Brandeis, J., dissenting).

53. Garrett, 531 U.S. at 375. There seems to be something to Justice Scalia's charge that Justice Kennedy can be "sententious." See PGA Tour, Inc. v. Martin, 532 U.S. 661, 704 (2001) (Scalia, J., dissenting) (decrying Justice Kennedy's stated satisfaction in his Garrett concurrence that the ADA will help promote a "decent, tolerant, progressive society").

54. Garrett, 531 U.S. at 375 (Kennedy, J., concurring).

55. United States Term Limits, Inc. v. Thornton, 514 U.S. 779, 838 (1995) (Kennedy, J., concurring).

56. Garrett, 531 U.S. at 375-76 (Kennedy, J., concurring). But see Bush v. Gore, 531 U.S. 98, 105 (2001) (per curiam) (assessing whether the state satisfied its "obligation to avoid arbitrary and disparate treatment"); Vill. of Willowbrook v. Olech, 528 U.S. 562, 565 (2000) (observing that allegations of "irrational and wholly arbitrary" treatment, "quite apart from the Village's subjective motivation, are sufficient to state a claim for relief under traditional 
constitutionally reliable. Congress may not impose money damages against the states to enforce "a new awareness, a new consciousness, a new commitment to better treatment of those disadvantaged by mental or physical impairments .... ${ }^{n 57}$

Upon reflection, the last quoted statement is even more striking than it first appears. Recall that Justice Kennedy began his concurring opinion with "our own human instincts" and "the better angels of our nature. ${ }^{n 58}$ Yet by the end of his brief concurrence, Kennedy and O'Connor had begun to refer to people with disabilities not as "us" (nor even as "those among us") but rather as "those disadvantaged. ${ }^{59}$ The struggle between human instincts and better angels was resolved, the better angels had been crushed.

The states may be "neutral entities," but the Court must protect their dignity. It must intervene against the clear wishes of Congress in order to assure that these sovereigns are not insulted. The states-even when they function in the role of employers-may not be held liable to a national antidiscrimination commitment. Rather, as neutral vessels, they respond accountably to the wishes of their citizens. Somehow, those state citizens presumptively approve hiring and firing decisions by the state bureaucracy-even if those decisions involve discrimination based on disability.

"It is a most serious charge," Kennedy explained, "to say a State has engaged in a pattern or practice designed to deny its citizens the equal protection of the laws, particularly where the accusation is based not on hostility but instead on the failure to act or the omission to remedy. ${ }^{\text {"60 }}$ Because such a failure or omission "does not always constitute" proof of an adequately egregious discriminatory pattern or practice, Kennedy assumed that they never will-unless there is the "predicate" of "the documentation of patterns of constitutional violations committed by the State in its official

equal protection analysis"); City of Cleburne v. Cleburne Living Ctr., 473 U.S. 432, 448 (1985) (finding no rational basis for, and thereby invalidating, application of city ordinance to home for those with mental disabilities).

57. Garrett, 531 U.S. at 376 (Kennedy, J., concurring) (emphasis added).

58. Id. at 375 (Kennedy, J., concurring).

59. Id. (Kennedy, J., concurring).

60. Id. (Kennedy, J., concurring). In sharp contrast, the majority in Bush v. Gore appeared to accept the petitioners' core claim described by Justice Stevens as "an unstated lack of confidence in the impartiality and capacity of the state judges who would make the critical decisions if the vote count were to proceed." Bush, 531 U.S. at 128 (Stevens, J., dissenting). 
capacity. ${ }^{n 61}$ If such adequate "judicial documentation" ever is found, of course, then the very courts that provided that documentation are ready and able to remedy "patterns of constitutional violations." No congressional action would be required.

The "neutral entities" of the states, therefore, have little to worry about from any federal concern to protect "those disadvantaged by mental or physical impairment. ${ }^{.62}$ Ironically, Justice O'Connorherself a victim of breast cancer-joined Kennedy in ignoring the fact that Patricia Garrett was a victim of both breast cancer and state employment discrimination. ${ }^{63}$ Along with other people Congress sought to protect under the ADA, Patricia Garrett surely ought to have counted as one of "us," rather than facing callous dismissal by the Court as well as by her employer. There was absolutely no connection between Patricia Garrett's breast cancer and her capacity to perform her job as Director of Nursing. ${ }^{64}$ As someone within the anonymous mass of "those disadvantaged," however, she now could have no claim against her state employer.

Initial recognition of the $\mathrm{ADA}$ as a significant "milestone on the path to a more decent, tolerant, progressive society ${ }^{365}$ is rapidly transmuted into another kind of stone. Sisyphus comes to mind. Abstractions have become "dispositive" and states' rights concepts must shield "neutral entities." "Those disadvantaged" cannot hope to budge such an elusive and massive stone wall.

61. Garrett, 531 U.S. at 375-76 (Kennedy, J., concurring).

62. Id.

63. Other Justices, as well as Justice O'Connor, have suffered from diseases and physical ailments that might be classified as "disabilities." What they apparently have not encountered, however, is clear discrimination because of such disabilities. Thus an understandable fear of crowded dockets, perhaps compounded by the kind of anxiety about diminished abilities that is common among many of us as we reach the "certain ages" of the Justices, seems to have triumphed over deference to what Congress said and did. It certainly swamped the Justices' ability to get outside themselves, and to empathize with people who seem different. See generally Soifer, supra note 14, at 1287-90.

64. Garrett underwent a lumpectomy, radiation treatment, and chemotherapy, and was informed when she returned to work that she would have to give up her position as Director of Nursing, OB/Gyn/Neonatal Services at the University of Alabama in Birmingham Hospital. The plaintiff in a companion case that reached the Court, Milton Ash, received poor performance evaluations after the Alabama Department of Youth Services denied him a transfer recommended by his doctor because of his chronic asthma and sleep apnea. See Garrett, 531 U.S. at 362.

65. Id. 


\section{II. "A Benevolent Compassion That the law Does not Place IT WITHIN OUR POWER TO IMPOSE ${ }^{766}$}

By contrast, PGA Tour, Inc. v. Martin ${ }^{67}$ suggests a kind of nested Russian doll. The case may be hard to take entirely seriously. For one thing, it seems so easily confined to its facts: the very unusual circumstance of an extraordinarily talented, dedicated plaintiff who has a clear, rare disability, yet who still does exceptionally well competing in a commercial sports event that actually is open to anyone willing to pay a hefty entrance fee to enter the competition. ${ }^{68}$ But on closer scrutiny, the Martin case actually brimmed over with an intricate play within a play. Ultimately, a specific and very commercial series of acts turned out to be "the thing."69

There is much to be learned as we follow the course in Martin. First, there are important aspects of the crucial metaphor of what constitutes a level playing field, developed in the apt setting of golf. These became crucial matters not only within a game in which carrying a handicap is a familiar construct, but also in the larger realm of what accommodations we might be obliged to make for persons with disabilities. Martin also illuminates the increasingly contested issue of how public accommodations should be defined and governed. Finally, the Martin decision suggests that there ought to be substantial middle ground between familiar, somewhat threadbare dichotomies such as public/private and action/inaction. The Court's holding in Martin, that a limited specific accommodation did not fundamentally alter the ancient game of golf, heightened the visibility of its decision-as well as the sarcasm and ire of the dissenters.

66. PGA Tour, Inc. v. Martin, 532 U.S. 661, 691 (2001) (Scalia, J., dissenting).

67. 532 U.S. 661 (2001).

68. In addition to the hefty entrance fee, two letters of recommendation were required; the majority asserted that this did not create a meaningful barrier. Martin, 532 U.S. at 67980. Scalia's dissent did not dispute this point.

69. WILlLAM SHAKESPEARE, HAMLET act 2, sc. 2 (A.R. Braunmuller ed., 2001). 


\section{A. An Intensively Fact-Based Inquiry ${ }^{70}$}

To the majority, the Martin case presented two essential questions: (1) whether the ADA protected access to professional golf tournaments for tournament participants and (2) whether a disabled competitor could be denied the use of a golf cart on the grounds that to allow him to use a cart would "fundamentally alter the nature" of the tournament? ${ }^{71}$

Strikingly, the Court's answers to these questions-yes, the ADA reached Casey Martin's situation; and no, it did not alter golf fundamentally to allow him to ride in a golf cart, even while competing in golf's top tournaments-generated great public response. ${ }^{72}$ Many of those who passionately attacked the decision entirely missed the nuanced, fact-specific nature of Justice Stevens' majority opinion. Actually the seven-to-two majority closely followed the fact-finding and analysis of the lower courts. ${ }^{73}$

Thus, for example, while conceding that fatigue and stamina were key elements in famous tournament outcomes, ${ }^{74}$ Stevens observed that the ADA's "basic requirement" is "that the need of a disabled person be evaluated on an individual basis ...."75 That inquiry revealed that even when Martin rides on a cart, he "must walk over a mile during an eighteen-hole round," and "the fatigue he suffers from coping with his disability is 'undeniably greater' than the

70. Martin, 532 U.S. at 673 (quoting Martin v. PGA Tour, Inc., 204 F.3d 994, 1000 (9th Cir. 2000)).

71. Id.

72. In the days immediately following the decision, radio talk shows were full of discussions about the case and newspaper stories, columns, and editorials also discussed it vigorously. Opinions seemed-at least to one casual observer-to be closely divided between who were for and against (as well as pro and amateur). It may be, as Hunter Thompson once observed (quoting Raoul Duke), "When the going gets weird, the weird turn pro." HUNTER S. THOMPSON, The Great SHark HuNT: STRANGe Tales From a Strange Time v (1979).

73. Martin, 532 U.S. at 671-79 (reviewing the lower court's analysis of whether the PGA Tour was a public accommodation, and whether the purpose of the rule at issue could reasonably be modified without frustrating the intent of the rule).

74. Id. at 674 (citing the experiences of Ken Venturi and Ben Hogan); see also Olinger v. United States Golf Ass'n, 205 F.3d 1001 (7th Cir. 2000), vacated by 532 U.S. 1064 (2001).

75. Martin, 532 U.S. at 690 (relying upon Sutton v. United Air Lines, Inc., 527 U.S. 471, 483 (1999), and the Court's rejection of any equivalence between "outcome affecting" and "fundamentally altering"). 
fatigue his able-bodied competitors endure from walking the course."

The Court also rejected an asserted conflict between Titles I and III of the ADA, and with it the PGA's claim that Martin could only bring a "job-related" discrimination claim under Title I. ${ }^{77}$ In fact, said the Court, even if Title III were held to be restricted to "clients [and] customers," as the PGA argued, "it would be entirely appropriate to classify the golfers who pay petitioner $\$ 3,000$ for the chance to compete in the Q[ualifying]-School and, if successful, in the subsequent tour events, as petitioner's clients or customers." ${ }^{m 8}$ Stevens maintained that the tournament actually had two sets of clients or customers: those who paid to watch and those who paid to play. In fact, the high entry fee structure readily distinguishes the PGA Tour from the parade of horribles described in Scalia's dissent. ${ }^{79}$ It also suggests, however, how easy it would be for the PGA simply to alter its entry fee arrangement, through which "any golfer with the requisite letters of recommendation acquires the opportunity to qualify for and compete in petitioner's tours. ${ }^{n 80}$

In an important sense, Martin's emphasis on fact-specificity means it is not much of a precedent for other situations. That said, Martin has great symbolic importance. The majority's willingness to find some middle ground (even on a golf course) on which there must be reasonable accommodation suggests a view of discrimination that is the antithesis in several important respects of Garrett's willful embrace of hardheaded and hard-hearted discriminatory conduct.

76. Martin, 532 U.S. at 671-72.

77. Id. at $678-82$.

78. Id. at 679-80. Scalia's dissent did not respond to this point about economics. In fact, soon after the ADA passed, one of the authors of the Act mentioned that golf courses were covered by the statute, and regulations implementing the ADA supported this view. See Robert L. Burgdorf, Jr., The Americans with Disabilities Act: Analysis and Implications of a Second-Generation Civil Rights Statute, 26 HARV. C.R.-C.L. L. REV. 413, 423 (1991).

79. Scalia warned that down the slippery slope established by the Martin decision there would be claims to have four strikes allowed in Little League games and other such radical changes in the rules of various sports. Martin, 532 U.S. at 702-03.

80. Id. at 680. "Any member of the public may enter the Q-School by submitting two letters of recommendation and paying a $\$ 3,000$ entry fee to cover greens fees and the cost of golf carts, which are permitted during the first two stages, but have been prohibited during the third stage since 1997." Id. at 661 . 
To the Martin Court, the ADA is directly analogous to the Civil Rights Act of 1964, both in its specific coverage and on a deeper level. Under either statute, one who owns or operates a place of public accommodation has a duty not to discriminate, notwithstanding whatever business sense or fiscal interest might surround such discrimination. Like race, disability may not be the basis for invidious discrimination. Moreover, Title III specifically defines "discrimination" as "a failure to make reasonable modifications in policies, practices, or procedures ... necessary to afford" a broad range of goods, services, and so forth to individuals with disabilities. $^{81}$

As discussed below, the idea of discrimination as a failure to act is vitally important-though it is also generally anathema to the current Justices. That Martin was a seven-to-two decision, with only Scalia and Thomas dissenting, emphasizes how sympathetic Casey Martin was as a plaintiff. It also suggests how skillfully Stevens wove together his interpretation of the cloak of ADA coverage-but also how limited the reach of the Martin decision is likely to be.

In fact, Stevens summarized the decision in a way that emphasized its limits: "A modification that provides an exception to a peripheral tournament rule without impairing its purpose cannot be said to 'fundamentally alter' the tournament." Thomas, dissenting, the Martin opinion was anything but a mere modification on the periphery. Instead, Scalia scolded, Stevens provided an answer to an "incredibly difficult and incredibly silly question" concerning what is "essential" to golf. ${ }^{83}$ The Court's response was "quite absurd," according to Scalia, who added that the majority's intrusion violated "the very nature of competitive sport," which is "the measurement, by uniform rules, of unevenly

81. Id. at 682 (quoting 42 U.S.C. \& 12182(b)(2)(A)(ii) (2000)):

A failure to make reasonable modifications in policies, practices, or procedures, when such modifications are necessary to afford such goods, services, facilities, privileges, advantages, or accommodations to individuals with disabilities, unless the entity can demonstrate that making such modifications would fundamentally alter the nature of such goods, services, facilities, privileges, advantages, or accommodations.

Id. Stevens explained that requirements of accommodation are merely extensions to provide citizens with disabilities a chance to compete and enjoy the job functions of the workplace with other non-disabled employees.

82. Martin, 532 U.S. at 690.

83. Id. at 700 (Scalia, J., dissenting). 
distributed excellence. ${ }^{n 44}$ Scalia's outraged dissent-extreme even for a Justice known for his rhetorical firebombs-is illuminating about judicial concern for essences and the nature of things and people.

\section{B. "Misty-Eyed Judicial Supervision of a Revolution"85}

Scalia made it clear that he disagreed with the Court's use of its authority to interpret the ADA. He decried the majority's invocation of power to exercise "a benevolent compassion" ${ }^{\text {"86 }}$ and to undertake "misty-eyed ... supervision ${ }^{\mathrm{n7} 7}$ of what he characterized as an illegitimate revolution. And that was just for openers. In his single, penultimate sentence, for example, Scalia termed the majority decision "Kafkaesque;" condemned "its Alice in Wonderland determination that there are such things as judicially determinable 'essential' and 'nonessential' rules of a made-up game;" and derided its "Animal Farm" notion of fairness. ${ }^{88}$ Beyond stacking literary sources, Scalia made it plain throughout his dissent that the majority had struck a nerve. For instance-perhaps put sharply, even for Scalia-he suggested at one point that in construing the ADA as they did, his fellow Justices lacked either humility or selfrespect. ${ }^{89}$ To Scalia, "the rules are the rules ${ }^{190}$-and the PGA must remain the ultimate rulemaker. Neither Congress nor the Supreme Court ought to have any say in the matter. The rules of golf are outside or beyond legal regulation. ${ }^{91}$

84. Id. at 703 (Scalia, J., dissenting).

85. Id. at 704 (Scalia, J., dissenting).

86. Id. at 691 (Scalia, J., dissenting).

87. Id. at 704 (Scalia, J., dissenting).

88. Id. at 705 (Scalia, J., dissenting). Scalia concluded his remarkable sentence, "The year was 2001, and 'everybody was finally equal."' ld. (citing Kurt Vonnegut, Harrison Bergeron, in ANIMAL FARM AND RELATED READINGS 129 (1997)).

89. Martin, 532 U.S. at 700-01 (Scalia, J., dissenting). "Either out of humility or out of self-respect (one or the other) the Court should decline to answer this incredibly difficult and incredibly silly question." Id. at 700 (Scalia, J., dissenting). This particular Scalia binary choice refers to whether walking is a fundamental aspect of golf. To Scalia, the Court engaged in defining "classic, Platonic golf," id. at 700, in making the judgment required by the ADA as to whether a "reasonable modification ... would fundamentally alter the nature of such goods, services, facilities, privileges, advantages, or accommodations." 42 U.S.C. § $12182(\mathrm{~b})(2)(\mathrm{A})(\mathrm{ii})(2000)$.

90. Martin, 532 U.S. at 700 (Scalia, J., dissenting).

91. Id. 
It is hardly self-evident that Scalia's own pronouncements display the virtues of deference. One even might say that the very essence of Scalia's condemnation is that the PGA is private, and, therefore, unreached and perhaps unreachable by the ADA-or by Congress generally. ${ }^{92}$ This, too, is a species of Platonic essentialism. Combined with the Court's refusal to defer to Congress in Garrett and its other recent decisions intervening in the name of federalism, Scalia's position would establish a broad expanse of both public and private discriminatory conduct exempt from federal law ${ }^{93}$ Scalia is among the primary shapers of an extreme, essentialist view of federalismconcededly not a direct nor strict construction of any constitutional text. $^{94}$

A key distinction, illuminated by Scalia's dissent in Martin, rests on two connected claims. First, he maintained that the PGA Tour simply cannot be a public accommodation offering "good, service, facility, privilege, advantage, or accommodation" covered by Title III of the ADA. ${ }^{95}$ Rather the PGA Tour is akin to the California Bar Examination, an open audition for a movie or play, or an open tryout for a baseball team. ${ }^{96}$ A professional golfer cannot be a buyer of anything offered by a public accommodation; he must be exclusively a seller, and thus someone who simply cannot "enjoy" his work at all. Scalia would strictly separate the ADA's Title I, covering employment discrimination, from Title III, which covers the enjoyment of public accommodations. For Scalia, in fact, much turns on a circular definition he provided: "The only distinctive feature of places of public accommodation," he proclaimed, "is that they accommodate the public ...." ${ }^{n 97}$ Being public in this sense is no

92. In United States v. Morrison, 529 U.S. 598 (2000), for example, Chief Justice Rehnquist's majority opinion relied upon but also echoed the tragic whipsaw of the Civil Rights Cases, 109 U.S. 3 (1883). The Court claimed that because the Fourteenth Amendment deals only with the actions of state officials, Congress may not utilize its enforcement power, based on Section Five of the Fourteenth Amendment, to reach the actions of private individuals who committed criminal acts motivated by gender bias. Morrison, 529 U.S. at 619 21.

93. See Judith Resnik, Categorical Federalism: Jurisdiction, Gender, and the Globe, 111 YALE L.J. 619 (2001).

94. See, e.g., Fla. Prepaid Postsecondary Educ. Expense Bd. v. Coll. Sav. Bank, 527 U.S. 627 (1999) (Scalia, J.); Blatchford v. Native Vill. of Noatak, 601 U.S. 775 (1991) (Scalia, J.).

95. Id. at 696 (Scalia, J., dissenting) (citing 42 U.S.C. $\$ 12182$ (b)(2)(A)(ii) (2000)).

96. Id. at 696-97 (Scalia, J., dissenting).

97. Id. at 694 (Scalia, J., dissenting). His full statement was: "The only distinctive feature 
different from being private. The public/private distinction collapses entirely. Because of Scalia's pinched sense of what a public accommodation is, however-it has no essence, and may be an empty, tautological set-it seems to follow that Congress may not be permitted to treat public accommodations differently from other businesses. ${ }^{98}$

Second, according to Scalia, the majority read the ADA to mandate a "ridiculous thing," which he described as "one set of rules that is 'fair with respect to the able-bodied' but 'individualized' rules ... for "talented but disabled athletes." particular must be strictly kept apart. Otherwise, the managing bodies of sports in effect are being told by the Court to "try to take account of the uneven distribution of God-given gifts when writing and enforcing the rules of competition." ${ }^{100}$ One rule must fit all. This is true of professional sports, no matter how open the qualifying stages, and it should be true of the world generally. Tinkering by law-legislative, administrative, or judicial-interferes with the God-given natural state.

Scalia sardonically condemned the majority for its concern for "classic, Platonic golf." ${ }^{\text {"101 }}$ Yet the essentialist worldview of private ordering that Scalia advances could hardly be more clearly the workproduct of a Platonic Guardian at full throttle. As we will see, the definition of "public accommodations," as well as the need for contextual attention to what would constitute a reasonable accommodation, should not and cannot disappear. Scalia may be pushing hemlock as the Socratic solution to regulations dealing with disability, but the real world continues to intrude.

of places of public accommodation is that they accommodate the public, and Congress could have no conceivable reason for according the employees and independent contractors of such businesses protections that employees and independent contractors of other businesses do not enjoy." Id. (emphasis in original).

98. Given that for Scalia the category of "public accommodation" is so narrow as possibly to be a vacuum-perhaps a legal concept with no essence at all-there may be a lurking invitation for advocates to challenge public accommodation laws and regulations on broad constitutional grounds. If a regulatory category lacks any basis for the differential treatment the government applies, any such treatment could be thought to violate either recent equal protection or takings law precedents. See, e.g., Vill. of Willowbrook v. Olech, 528 U.S. 562 (2000), and cases discussed supra note 5 .

99. Martin, 532 U.S. at 703 (Scalia, J., dissenting).

100. Id. at 703-04 (Scalia, J., dissenting).

101. Id. at 700 (Scalia, J., dissenting). 


\section{DisCRIMINATION AND POSITIVE LAW: “THE ADA DOES NOT ONLY MANDATE That INDIVIDUALS WITH DISABILITIES BE Treated the SaMe As PERSONS Without SuCH DisabILITIES" ${ }^{\text {102 }}$}

Scalia argued in his Martin dissent that even if the PGA Tour were considered a public accommodation for Title III purposes, the $\mathrm{ADA}$ offers no basis to inquire whether alterations are required once access is granted. To illustrate a distinction between possibly permissible regulation of access, but clearly impermissible regulation of content, Scalia quoted at length from a Seventh Circuit opinion written by Chief Judge Posner. ${ }^{103}$

In Doe v. Mutual of Omaha Insurance Co., ${ }^{104}$ Posner held that an insurance company's selective cap on policy benefits for AIDS or AIDS-related conditions did not violate Title III of the ADA. Mutual of Omaha stipulated that it "has not shown and cannot show" that its low lifetime benefits limits "are or ever have been consistent with sound actuarial principles, actual or reasonably anticipated experience, bona fide risk classification, or state law." ${ }^{105}$ Yet the insurance company prevailed. Even if the mere mention of insurance law seems intimidating, it is worth examining some deeper elements of Posner's decision. His reasoning has significance well beyond the realm of insurance. ${ }^{106}$

Characteristically, Posner utilized telling analogies as he rejected the claim of discrimination in the caps allegedly prohibited by the ADA. Unsupported (and, by stipulation, unsupportable) insurance policy limits are acceptable, Posner held, utilizing a central, extended analogy to a camera store ${ }^{107}$ Even if Posner's argument were not such a good example of the classic law school concern about what happens when you let the camera get its nose in the tent, his

102. Zimring v. Olmstead, 138 F.3d 893, 899 (11th Cir. 1998), affd, Olmstead v. Zimring, 527 U.S. 581 (1999).

103. See Martin, 532 U.S. at 698.

104. 179 F.3d 557 (7th Cir. 1999), cert. denied, 528 U.S. 1106 (2000).

105. Id. at 558 (citing Mutual of Omaha's stipulation).

106. Posner does have a relatively expansive view of the definition of public accommodation that goes beyond the physical and covers intangibles.

107. Mutual of Omaha, 179 F.3d at 560. 
focus usefully captures substantial elements of several basic ADA issues. $^{108}$

The part of Posner's opinion quoted in Scalia's Martin dissent first observed: "The common sense of the statute is that the content of the goods or services offered by a place of public accommodation is not regulated." ${ }^{109}$ Perhaps consistent with the postulates of law and economics, this claim of common sense is otherwise unsupported. It is also far from obvious within a sweeping regulatory reform regime such as the ADA. Yet this presumed common sense baseline turned out to be the key to Posner's answer to the central question throughout his entire opinion. It turned out to be yet another challenging Posner Analogy Test.

\section{A. The Camera Lens}

Posner's first analogy underscored the limitation he hoped to impose on the ADA's language: " $A$ camera store may not refuse to sell cameras to a disabled person, but it is not required to stock cameras specially designed for such persons. ${ }^{m 110}$ Discretionary choices by both merchant and market must prevail once access is guaranteed. To Judge Evans, dissenting, "The better analogy would be that of a store which lets disabled customers in the door, but then

108. In an article in October 1, 2001 New Yorker, Susan Sontag pointed out that several authors have noted the melancholy nature of the camera. Susan Sontag, Loving Dostoevsky: The Recovery of the Novel "Summer in Baden-Baden," Tre New Yorkren, Oct. 1, 2001, at 98.

109. Martin, 532 U.S. at 698 (Scalia, J., dissenting) (quoting Doe v. Mutual of Omaha Ins. Co., 179 F.3d 657, 560 (7th Cir. 1999)) (admitting that the statutory language is not clear, contrary to Scalia's general approach, but also remaining unclear as to the source of this "common sense").

110. Id. at 698 (Scalia, J., dissenting) (quoting Mutual of Omaha, 179 F.3d at 560). Scalia went on to quote more of Posner's majority opinion, joined by Easterbrook:

The common sense of the statute is that the content of the goods or services offered by a place of public accommodation is not regulated. A camera store may not refuse to sell cameras to a disabled person, but it is not required to stock cameras specially designed for such persons. Had Congress purposed to impose so enormous a burden on the retail sector of the economy and so vast a supervisory responsibility on the federal courts, we think it would have made its intention clearer and would at least have imposed some standards. It is hardly a feasible judicial function to decide whether shoestores should sell single shoes to one-legged persons and if so at what price, or how many Braille books the Borders or Barnes and Noble bookstore chains should stock in each of their stores.

Id. 
refuses to sell them anything but inferior cameras." ${ }^{111}$ Much turns on which analogy is more apt. Indeed, the distinction Posner sought to draw turns out to be key beyond his Mutual of Omaha decision. It also illuminates the arguments among the Justices in Martin and in other ADA cases, and hints at what a better approach might be.

The "core meaning" of the public accommodation provision in the ADA is clear, according to Posner. ${ }^{112}$ It is "plainly enough ... that la facility] open to the public cannot exclude disabled persons from entering the facility and, once in, from using the facility in the same way that the nondisabled do."113 It necessarily follows, Posner proclaimed, that " $[t]$ he owner or operator of, say, a camera store can neither bar the door to the disabled nor let them in but then refuse to sell its cameras to them on the same terms as to other customers."114 It is noteworthy that Posner-who elsewhere has insisted on the constitutionally crucial importance of distinguishing between negative and affirmative guarantees of rights ${ }^{15}$-here perceived no significance to the distinction between a request "that a limitation be removed rather than that a physical product be added or altered."116 The lens cap is either on or off. The merchant is seen only in binary terms-refusing service altogether, or serving all customers "in the same way" and "on the same terms." Within the black box of the Common Sense Camera Store, either the merchant's free choice or the disabled customer's demand must prevail. There is no middle ground. No accommodation need be made, despite what the ADA has to say about "reasonable accommodation" required to provide "full and equal enjoyment."117

\section{B. Logging More Analogies}

To be sure, Posner's position began to seem more plausible in the course of two additional analogies he suggested. He immediately went on to state (and Scalia to quote): "It is hardly a feasible judicial

111. Mutual of Omaha, 179 F.3d at 565 (Evans, J., dissenting).

112. Id. at 559.

113. Id.

114. Id.

115. See DeShaney v. Winnebago County Dep't of Soc. Servs., 812 F.2d 298 (7th Cir. 1987), affd, 489 U.S. 189 (1989).

116. Mutual of Omaha, 179 F.3d at 560.

117. 42 U.S.C. $\$ 12182(2000)$. 
function to decide whether shoestores should sell single shoes to one-legged persons and if so at what price, or how many Braille books the Borders or Barnes and Noble bookstore chains should stock in each of their stores." ${ }^{\text {n18 }}$ Thus, Posner identified a twofold central concern: First, he worried about the burden of an explosion of cases in the federal courts; and second, he feared that these judges would be required to make "standardless decisions about the composition of retail inventories." ${ }^{\text {"119 }}$ These rather extreme examples do push us far along the slippery slope of intimate regulation of the marketplace, backed by unceasing judicial scrutiny. They also depend, however, on a radical hypothetical leap away from the stipulated facts in Mutual of Omaha-to say nothing of the glaring distance of these analogies from insurance, a heavily regulated industry that deals in products hardly closely akin to the kind of free market camera shops, shoe stores, and bookstore chains in the hypotheticals Judge Posner so enjoys.

That said, Posner did go on to concede that the AIDS insurance caps initially might seem disanalogous to the "refusal to stock" the special item hypotheticals. ${ }^{120}$ This was because a person infected by HIV who contracted pneumonia faced a very low benefits cap; a person not infected by HIV would find the costs of treating his pneumonia fully covered. ${ }^{121}$ Posner observed: "It looks, therefore, like a difference in treatment referable solely to the fact that one person is disabled and the other is not. ${ }^{n 22}$ Posner immediately added, however: "But this is not correct." ${ }^{\text {"23 }} \mathrm{He}$ then offered a discursus explaining that HIV does not cause, but simply allows, other opportunistic diseases. Therefore, the AIDS cap actually deals acceptably with a distinctive disease. ${ }^{124}$ Convincing or not on this point, Posner also read the McCarran-Ferguson Act to bar ADA coverage of such insurance matters.

118. Mutual of Omaha, 179 F.3d at 560, quoted in PGA Tour, Inc. v. Martin, 532 U.S. 661, 668 (Scalia, J., dissenting). As if small bookstore owners did not have enough trouble competing with the massive chains, they ought to wonder about such product placement within a fictional judicial analogy.

119. Mutual of Omaha, 179 F.3d at 560.

120. Id.

121. Id.

122. Id.

123. Id. at 560 .

124. Id. at 561 . 
We need not plunge into the intricacies of either AIDS etiology or insurance law to notice that even Posner seemed to concede a problem when there is " $a$ difference in treatment referable solely to the fact that one person is disabled and the other not."125 Thus, he suggested, an insurance company cannot simply refuse to sell an insurance policy to a person with AIDS. ${ }^{126}$

In fact, the Second Circuit has held that such stonewallingspecifically, the refusal by the Allstate Insurance Company to sell a joint life insurance policy to a married couple each of whom had disabilities-violates the ADA's public accommodation protections. In Pallozzi v. Allstate Life Insurance Co. ${ }^{127}$ Judge Leval held that Title III, which covers underwriting practices, is not barred by the McCarran-Ferguson Act, and does not impose a burden on the plaintiff to show the absence of an actuarial basis for the claimed discrimination. ${ }^{128}$ Nonetheless, the Second Circuit implied-and that Court and a number of other circuits as well have elsewhere clearly held - that not all distinctions made on the basis of disability constitute discrimination banned by the ADA. For example, it is widely agreed that insurance companies may distinguish between physical and mental disabilities in establishing benefit policy caps without violating the $\mathrm{ADA} .{ }^{129}$

So what, if anything, is wrong with Posner's analogies or his holding? He proposes tough cases for defenders of ADA coverage. One need not embrace court-enforced merchandising, however, to believe that, by passing the $\mathrm{ADA}$, Congress gave previously unenforced or underenforced dignitary claims made by people with

125. Id. at 560 .

126. Id. at 559. Posner mentioned, however, that an insurance company defendant might be able to plead a special fundamental alteration defense of such a refusal. Id. It seems ironic for Posner, a prolific writer and important thinker who has devoted many pages to the importance of price in even some of the most improbable settings, not even to suspect that an artificially low benefit package might be the functional equivalent of a forbidden refusal to sell.

127. 198 F.3d 28 (2d Cir. 1999).

128. Id.

129. EEOC v. Staten Island Sav. Bank, 207 F.3d 144, 148 (2d Cir. 2000) (citing numerous other circuits similarly allowing the distinction). These decisions may be correct. They can be distinguished from Posner's Mutual of Omaha holding, however, on the basic ground that the factual predicate for the distinctions as to policy limits advanced by the companies in question seemed to rest on significant factual differences-a defense undermined in the Seventh Circuit case by Mutual of Omaha's stipulation, though Posner worked to rehabilitate such a defense in spite of the record. 
disabilities at least a practical leg to stand on (as it were) in their search for full and equal treatment with the rest of society. Nor is it necessary to speculate about how many Braille volumes must be on the shelves to perceive that an unmarked pitfall on the floor-though equally unmarked for all customers-still might violate the ADA rights of a blind customer.

Another analogy, discussed by Judge Evans in his dissent in Mutual of Omaha, further clarifies the matter. Evans wrote:

We are not being asked to force a restaurant to alter its menu to accommodate disabled diners; we are being asked to stop a restaurant that is offering to its nondisabled diners a menu containing a variety of entrees while offering a menu with only limited selections to its disabled patrons. ${ }^{130}$

As a result of the insurance company's stipulation indicating no rational basis for the benefits cap distinction and because of the harm done to people with disabilities, Evans' analogy seems more apt than Posner's comparison to even-handed treatment by camera shops, shoe stores, and bookstore chains. ${ }^{131}$

It is as if, in the context of AIDS, Mutual of Omaha is offering not an inferior camera, but one with which one can only "pretend" to take pictures. An insurance policy with an AIDS cap seems even less an insurance policy for an AIDS victim than a golf tournament without a cart is a fair competition for Casey Martin. Martin can still play all eighteen holes-he just will not win. The AIDS victim, however, cannot make it past the second hole. ${ }^{132}$ In rejecting the PGA's claims, one might hope the Supreme Court is rejecting Posner's insurance analogies as well. This seems somewhat of a stretch, however, no matter how clear the Martin majority was in

130. Mutual of Omaha, 179 F.3d at 565 (Evans, J., dissenting). Finding the appropriate analogy is an important part of the legal craft, of course, as is distinguishing among different ways people may be legally "forced" to do things they would prefer not to do.

131. It is apparent that Posner did not approve of the stipulation, which he explained as an element of the company's trial strategy: trying to win big even with the stipulation, but having available the possibility of case-by-case attrition if the initial defense failed. Mutual of Omaha, 179 F.3d at 564. Indeed, Posner tried hard to distinguish away the stipulation itself in the course of his medical discussion.

132. I am grateful to Tom Baker, who is the Connecticut Mutual Professor and the Director of the Insurance Law Center at the University of Connecticut School of Law, for his helpful discussion of these insurance law issues. 
rejecting Scalia's stridency and his slippery sloping greens. Yet this battle of analogies itself underscores the complexity and significance of attention to the connections and distinctions among "same," "equal," and "full" rights, as well as the issue of "reasonable accommodation" to which we now turn.

\section{THE COURT's 2001 TERM: STRICT DECONSTRUCTION, SUMmaRY INJUSTICE?}

The ADA unquestionably includes a good deal of ambiguity, some purposeful and some not. Professors Silvers and Stein convincingly argued recently, for example, that Congress' decision to copy the ADA's central definition of "disability" from the Rehabilitation Act of $1974^{133}$ had substantial and unfortunate consequences. ${ }^{134}$ The ADA blurred some important distinctions between individuals in need of rehabilitation and individuals with varying capabilities for whom the ADA sought "to assure equality of opportunity, full participation, independent living, and economic self-sufficiency." Repeatedly, in its formal statement of findings and purposes, as well as in debates and the statutory language ultimately adopted, Congress identified and sought to remedy the impact of past discrimination, both purposeful and unintentional, on people with disabilities. A pervasive theme, in fact, was that discrimination persists in a broad range of "critical areas," including the first one listed: "employment."

By lifting its disability definition wholesale from the Rehabilitation Act, however, Congress somewhat muddled what has become a key distinction between being substantially limited in a major life activity (such as performing manual tasks) and being

133. 29 U.S.C. $\$ 794$ (2000). See generally Burgdorf, supra note 78 (analyzing the ADA from its drafters' point of view).

134. Anita Silvers \& Michael Ashley Stein, Disability, Equal Protection, and the Supreme Court: Standing at the Crossroads of Progressive and Retrogressive Logic in Constitutional Classification, 35 U. MrCH. J.L. REFORM 81 (Fall 2001/Winter 2002).

135. 42 U.S.C. $\$ 12101(\mathrm{a})(8)(2000)$. For a cogent, critical description of the "independent living" component of the ADA, see Samuel R. Bagenstos, The Americans with Disabilities Act as Welfare Reform, 44 WM. \& MARY L. REV. 921 (2003).

136. 42 U.S.C. \&12101(a)(3). It is impossible to look at Title I in its entirety and not to see that the thrust of the entire Title is employment discrimination. As discussed below, however, the Court's manipulations of definitions at the threshold of "disability" have managed to cast doubt on whether "working" is even within the scope of the Act's coverage. 
capable of performing social functions (such as working). That confusion, unpacked convincingly by Silvers and Stein, has allowed the Court to whipsaw both the major life activity and the working elements of ADA protections. Defendants now enjoy virtually an open season when they challenge any individual's self-identification as a disabled person. The dignity of persons with disabilities is vitiated, if not forgotten. Moreover, the substantial and significant overlap between antidiscrimination and accommodation is buried under an avalanche of purportedly clear "either/or" choices imposed by the Court. ${ }^{137}$

In fact, with powerful assistance from the Court's rewriting of the ADA, defendants have become remarkably successful in resisting and defeating ADA claims. ${ }^{138}$ Definitional circularities, expansive use of summary judgment, and various other threshold legal maneuvers now allow judges to push Title I disability claims quickly out of court. Virtually lost in the shuffle is recognition that "Congress passed the ADA primarily because it saw the systematically inferior treatment of disabled people as rising to the level of unconstitutional discrimination." ${ }^{n 9}$

Brief consideration of the Court's four ADA decisions during its 2001 Term will demonstrate the basic inconsistencies in the Court's approach. It also will suggest that the Justices continue to struggle against the ADA's emphasis on the importance of work. Finally, in

137. See Christine Jolls, Antidiscrimination and Accommodation, 115 HARV. L. REv. 642 (2001).

138. See Bagenstos, supra note 135 , at 923 \& n.1.

139. Silvers \& Stein, supra note 134 , at 111 . The internal inconsistencies within the Supreme Court's interpretation of how to determine if someone meets the statutory definition for disability are quite stark. I discussed elsewhere some of the deep incongruities within earlier decisions by the Court that essentially rewrite the ADA. These include determining that only one of Congress' findings must be given weight-and then aggressively read against the grain of Congress' large number of expansive findings-and emphasizing that an "individualized inquiry" is "mandated by the ADA." Sutton v. United Air Lines, Inc., 527 U.S. 471, 483 (1999). Otherwise, Justice O'Connor's majority opinion in Sutton warned, "persons often must be treated as members of a group of people, with similar impairments, rather than as individuals." Id. at 483-84. Yet for all its rhetoric about individual treatment, the Court also has held: (1) that the person claiming to be disabled must demonstrate that she fits within some recognized category defined as disabled; and (2) that any job discrimination she encounters actually must affect a class of jobs stretching far beyond the particular type of job she seeks or wants to keep. Moreover, she must remain disabled even if she mitigates her disability naturally or with assistance. The decisions that established such a hologram of individual/group perceptions, however, in fact failed to consider the actual contexts of the particular individuals before the Court. See Soifer, supra note 14, at 1300-12. 
what might pass as a technical explication of available remedies, the Court in Gorman actually returned to and expanded upon some of the worst aspects of Garrett.

\section{A. Work}

1. Toyota Motor Manufacturing v. Williams: ${ }^{140}$ "Performing Tasks That Are of Central Importance to Most People's Daily Lives $^{\text {"141 }}$

The problems Ella Williams had at her job seem rather typical, though she may have been a bit more willing to pursue her rights than are most employees. Williams began working in Toyota's manufacturing plant in Kentucky in the summer of 1990, soon after the ADA was adopted. She developed pain in her hands, wrists, and arms, and so Toyota assigned her modified duties. After a few conflicts over her health and her need for work restrictions, Williams apparently worked uneventfully in Quality Control Inspection Operations [QCIO] for three years. In 1996, however, Toyota decided that workers in QCIO should rotate through all four of the unit's processes. Williams began to experience pain once again, and she sought an accommodation to allow her to return to performing only the two QCIO processes that did not require much lifting or manual labor. Toyota refused; soon Williams lost her job. ${ }^{142}$

The district court granted summary judgment to Toyota. Williams had failed to persuade the judge that her physical impairment might qualify as a disability because, as the District Judge noted, her impairment had not "substantially limited" any "major life activity."143 The Sixth Circuit reversed, believing that Williams could "show that her manual disability involved a 'class' of manual activities affecting the ability to perform tasks at work. ${ }^{\text {n14 }}$ The Supreme Court unanimously rejected that standard and reversed

140. 534 U.S. 184 (2002).

141. Id. at 187.

142. There is some dispute about what occurred during December of 1996, but Williams sued under the ADA challenging both the failure to accommodate and the termination of her employment, as well as on other grounds. Id. at 189-90.

143. Id. at 191 (quoting unpublished district court opinion that quoted, in turn, the ADA's disability definition at 42 U.S.C. $\$ 12102(2)(A)(2000)$ ).

144. Williams v. Toyota Motor Mfg., 224 F.3d 840, 843 (6th Cir. 2000). 
the Sixth Circuit. ${ }^{145}$ The reasons given by Justice O'Connor for the Court are quite revealing.

Once again, the Court first bounced around a good deal, picking and choosing among regulations promulgated by various federal agencies charged to interpret and apply the $\mathrm{ADA}$ and its predecessor, the Rehabilitation Act of $1974 .{ }^{146}$ Justice O'Connor also provided a direct reprise of the Court's heavy reliance on dictionary definitions to understand what Congress intended in its disability definition references to a substantial (e.g., "considerable" or "essential") limit on one or more of the major (e.g., "important") life activities. ${ }^{147}$ After knocking down a strawperson- “[m]erely having an impairment does not make one disabled for purposes of the $\mathrm{ADA}^{n 148}$ - the Court used its selective smattering of dictionary definitions as sole support for a major logical leap: "Major life activities' thus refers to those activities that are of central importance to daily life. ${ }^{n 149}$ But in an individualized inquiry, how

145. Toyota, 534 U.S. at 202-03.

146. Grudgingly, the Court again accepted for purposes of this case, explicitly and pointedly without deciding, that the EEOC regulations at stake were reasonable. Id. at 194. On the very next page, however, when the EEOC regulations were closer to where the Court wished to go, O'Connor quoted at length from the EEOC's regulation, describing the definition of "substantially limited" as "[u]nable to perform a major life activity that the average person in the general population can perform." Id. at 195-96 (emphasis added).

147. Id. at 196-97 (relying on Webster's Third New International Dictionary and on the second edition of the Oxford English Dictionary). Actually "substantial" and "major" wind up sounding almost synonymous, particularly as Justice O'Connor quite selectively quoted from the dictionary sources she chose in order to make both words appear to require showings of very substantial, and even "essential" limitations on a person's capabilities. The best she could do with "major" actually was to quote a Webster's International comparative definition: "greater in dignity, rank, importance, or interest," and O'Connor herself added "important." 148. Id. at 195.

149. Id. at 197. Even if Webster's International were the best source for determining the meaning of a statute, O'Connor's prestidigitation is striking. A dictionary "greater" becomes the Court's "important" which-with the addition of a "thus"-has "central" added to the definition. To notice this wordplay is not a mere quibble. Indeed, the essence of the Court's holding in Toyota emerges in the very next sentence, in which the added "central" has become mandatory, a prerequisite for fitting into the ADA's definition of being disabled. To quote in full: "In order for performing manual tasks to fit into this category-a category that includes such basic abilities as walking, seeing, and hearing - the manual tasks in question must be central to daily life." Id. As if saying something enough makes it so, the Court repeated that "the central inquiry" now "must be whether the claimant is unable to perform the variety of tasks central to most people's daily lives" at both the beginning and the end of its opinion. Id. at 185,200 . Who said the center could not hold? 
can anyone measure what is of central importance unless one takes an individual at his or her word?

The Court offered a surprising answer. It was premised exclusively on a remarkable rule of construction: "[t]hat these terms need to be interpreted strictly to create a demanding standard for qualifying .... ${ }^{n 150}$ The only support the Court claimed for its miserly approach to an important civil rights statute was that otherwise too many Americans might be covered. ${ }^{151}$ But the Court did not stop there. It made another breathtaking leap, relying on a telltale "therefore," this time in place of a "thus." O'Connor followed her discussion of the perils of the numerical slippery slope with: "We therefore hold that to be substantially limited in performing manual tasks, an individual must have an impairment that prevents or severely restricts the individual from doing activities that are of central importance in most people's daily lives. ${ }^{\text {152 }}$

So how do we provide the individual assessment mandated by the ADA? Apparently through use of a blunt, massively group-oriented reference point, through comparison for example, to what is presumed to be of central importance in the daily lives of "most people. ${ }^{n 153}$ When it comes to the ADA, the much-touted virtues of

150. Id. at 197. According to O'Connor, this parsimonious definitional approach "is confirmed by the first section of the ADA, ${ }^{n}$ citing $\$ 12101$ and emphasizing Congress' estimate of forty-three million Americans with one or more physical or mental disabilities in 8 12101 (a)(1). Id. O'Connor played the numbers game before in Sutton v. United Air Lines, Inc., 527 U.S. 471, 487 (1999), and it was unconvincing there, too. See Soifer, supra note 14, at 1305-06. To read all of $\S 12101$ of the ADA, which contains Congress' "Findings and Purposes," is to see that if Congress' sweeping language confirms anything, it is actually the opposite of O'Connor's pinched rule of construction. The Queen of Hearts in Lewis Carroll's Alice in Wonderland comes to mind. LEWIS CARROLL, ALICE IN WONDERLAND (Donald J. Gray ed., W.W. Norton \& Co., 2d ed. 1992).

151. Here again, as she had for the Court in Sutton, O'Connor relied on Congress' estimate of forty-three million Americans with one or more physical or mental disabilities and argued that the number would have been higher if a more generous definition were employed. Sutton, 527 U.S. at 487. There are numerous fallacies in this argument, not least of which is that even people who might technically be defined as disabled also might not choose to define themselves that way or to invoke the ADA for a variety of reasons. That all Americans theoretically can claim the protections of 42 U.S.C. $\$ 1983$, for example, because all Americans are said to be of some race and to be protected from racial discrimination under color of state law does not mean that "race" or $\$ 1983$ must be "interpreted strictly to create a demanding standard for qualifying" under the statute. Toyota, 534 U.S. at 197.

152. Id. at 198. The impairment also must be either permanent or long-term, according to the Court.

153. Earlier in her opinion, O'Connor approvingly quoted several EEOC definitions that 
sticking to the text, restraining judicial activism, and assuring accountability by decision makers seem simply to melt away. Indeed, just when it seemed that the Justices could not possibly slice the bologna any thinner, they managed to do so again in Toyota.

The Sixth Circuit understandably believed after Sutton that "substantially limits" requires a showing of limits in a "class" of activities. The Supreme Court disagreed. Sutton did require "that plaintiffs allege that they are unable to work in a broad class of jobs;" ${ }^{154}$ the Sutton twins' ADA claim did not fly because they had not anticipated and did not satisfy that requirement. "But," the Court now explained, "Sutton did not suggest that a class-based analysis should be applied to any major life activity other than working. ${ }^{n 155}$ Moreover, the Court reiterated its concern about "the conceptual difficulties inherent in the argument that working could be a major life activity" and determined not to decide "this difficult question..156 It is a difficult question only because of the Court's interventions. The ADA hardly anticipated complicated litigation and massive barriers at the definitional stage of disability claims. Indeed, Title $I$ is almost entirely about employment and the workplace. And one must wonder if there is much doubt even using the Court's new ADA benchmark-what "most people" believeconcerning whether working is a major life activity.

The Sixth Circuit had not relied on "working," however. It found instead that Williams had substantial limits in her ability to do manual tasks associated only with her job. "This was error," the Justices announced. In referring to a "class of manual activities," the Sixth Circuit had been overly broad; but in considering manual

employ an "average person in the general population" standard. Id. at 195 (emphasis added). One is left to wonder whether the Court's subsequent move from "average" to "most people" is attributable to the Court's intention to raise the ante, or if it represents statistical or linguistic sloppiness.

154. Sutton, 527 U.S. at 491.

155. Toyota, 534 U.S. at 200. That issue was not before the Court in Sutton.

156. Id. at 200. The Sutton Court assumed, only for purposes of that decision, that working can constitute a major life activity. In Sutton's companion case, Albertson's, Inc. U. Kirkingburg, 527 U.S. 555 (1999), however, the Court simply assumed without discussion that working is a major life activity. The Court then disposed of the disability claim on other threshold grounds. Indeed, the Toyota Court mentioned in passing that Title I "deals with employment ...." Toyota, 534 U.S. at 201. It would seem hard to understand how "working" could possibly be excluded from its basic definition of disability. 
tasks associated with Williams' job, the Court of Appeals had been too narrow. The Court insisted that the crucial inquiry about an activity must be measured in terms of whether it is "central to most people's daily lives, not whether the claimant is unable to perform the tasks associated with her specific job. ${ }^{n 157}$ So much for Congress' evident effort throughout Title I to protect persons with disabilities from discrimination in employment. So much for the "individualized inquiry mandated by the ADA." ${ }^{158}$

\section{US Airways v. Barnett: ${ }^{139}$ "Preferences Will Sometimes Prove Necessary to Achieve the [ADA's] Basic Equal Opportunity Goal"160}

The Court was dramatically divided in Barnett, in sharp contrast to its unanimous agreement at least as to the results in the other ADA decisions under discussion. Yet the Barnett Court's treatment of the ADA was much less technically intricate. The Court's sharp divisions turned instead on the issues of how to define "neutrality," and how much the ADA might be understood to have changed the workplace.

157. Id. at 200-01. The Court simply asserted that Williams' inability to do the manual tasks required at work-" "repetitive work with hands and arms extended at or above shoulder levels for extended periods of time ... is not an important part of most people's lives." Id. at 201. Additionally, the Court seemed to go out of its way to stress the variability of impairment caused by carpal tunnel syndrome. Id. at 199.

Yet it was only by reframing the issue entirely-the disability definition is not really about work, it is about a wide range of other manual tasks-that the Court plausibly could claim a measure of support from what is important in "most people's daily lives." Indeed, O'Connor scolded the Sixth Circuit for not examining other manual tasks such as "household chores, bathing, and brushing one's teeth" which are, she proclaimed, "among the types of manual tasks of central importance to people's daily lives." Id. at 202. As a bald person who has many friends-both women and men-with short hair (or less), I wonder if daily hair-brushing meets the standard; at times, I'm not even sure how high daily bathing ranks among my fellow Americans on the central importance meter, notwithstanding the Court's specific assurance on the matter.

158. See supra note 150. Of course, Title I does not say that persons with disabilities should always get or keep the jobs they seek. Rather it clearly calls for a contextual inquiry about what is or is not a "reasonable accommodation," taking into account the burden on the employer as well as the burden on the employee. The following discussion of the Court's decisions in Barnett and Echazabal analyzes this element of the ADA and explores some of the Court's choices among competing values. See infra Parts II.A.2. and II.A.3.

159. 122 S. Ct. 1516 (2002).

160. Id. at 1521 . 
Justice Breyer's lead opinion-which prevailed only because Justice O'Connor voted to join so as to avoid a stalemate ${ }^{161}$ _ sought pragmatic middle ground under the ADA for "unprejudiced thought and reasonable responsive reaction on the part of employers and fellow workers alike." ${ }^{\text {"162 }}$ That ground became a battlefield within the Court, however, primarily because Breyer insisted that the ADA's "reasonable accommodation" requirement sometimes would require an employer to do more than simply to insist on applying a neutral rule or practice.

John Barnett, a long-time employee of US Airways and one of its predecessor airlines, injured his back while working as a cargohandler in 1990. He was able to transfer to a less physically demanding mailroom position, where he worked for two years. Upon learning that the position was to become open to seniority bidding and that two more senior employees planned to bid for the job, Barnett asked for an accommodation that would allow him to remain working in the mailroom. US Airways eventually decided to make no exception for him, and Barnett lost his job. Barnett then filed suit under the ADA, claiming that its requirement of a "reasonable accommodation" ought to prevail over a seniority system unilaterally imposed by his employer. ${ }^{163}$

Without delving deeply into the intricacies of the divisions within the Court, two elements of Breyer's plurality opinion stand out. First, Breyer's view of the ADA emphasized that even neutral

161. Justice Breyer was joined by Chief Justice Rehnquist and Justice Kennedy. Justice Stevens also joined Breyer's opinion, but he filed a concurrence, emphasizing how sparse the record was and what he saw as the issues and the burden upon remand. Justice O'Connor also joined but, quoting Justice Rutledge's concurrence in the famously divided Screws $v$. United States, 325 U.S. 91 (1945), expressed sigmificant doubts as to whether the position in question was "vacant" and whether the seniority system imposed by US Airways was legally enforceable. Justice Scalia dissented, joined by Justice Thomas, and simply would have deferred to the seniority system. Justice Souter, joined by Justice Ginsburg, read the ADA to trump the seniority system in place at US Airways and thus also dissented.

162. Barnett, 122 S. Ct. at 1523.

163. The district court granted summary judgment, holding that interfering with the airline's seniority system would cause it "undue hardship," an ADA standard that overcomes "reasonable accommodation." The Ninth Circuit reversed, en banc, regarding the seniority system as only "a factor" in the undue hardship analysis and calling for an intensive case-bycase inquiry to assess undue hardship. See Barnett v. US Airways, Inc., 228 F.3d 1105 (9th Cir. 2000). It bears noting that none of the Justices questioned whether Barnett's back injury actually disabled him at the definitional threshold, under the criteria established by the unanimous Toyota decision a few months before. 
employment rules-such as neutral rules governing office assignments or furniture budgets-actually can automatically operate to prevent the "reasonable accommodation" mandated by the ADA. To satisfy the ADA, in Breyer's opinion, "preferences will sometimes prove necessary to achieve the Act's basic equal opportunity goal."164

This caveat regarding inherent limitations within formal neutrality is important in itself. It also resonates directly with some of the Court's most important constitutional battles in recent years. In the Cleveland school voucher case, for example, Chief Justice Rehnquist insisted that the challenged voucher plan did not violate the Establishment Clause of the First Amendment because, as he repeated over and over, it was "neutral in all respects toward religion. ${ }^{\text {n165 }}$ With considerable passion, the dissenters took the majority to task for its use of the particular categories of funded programs that Rehnquist considered in order to declare the plan neutral, as well as for his use of "neutrality" in what they regarded as an inaccurately unified abstraction. ${ }^{166}$ Much of the roiling debate about "affirmative action" also continues to revolve around issues of neutrality and questions about when and if preferences may or should count.

Second, Barnett is noteworthy for the plurality's description of the main purpose of the ADA. Breyer wrote in terms quite difficult to reconcile with the vision of the ADA described in Toyota-a decision in which all the Justices joined. According to the plurality in Barnett, the ADA's "primary purpose" is to seek "to diminish or to eliminate the stereotypical thought processes, the thoughtless actions, and the hostile reactions that far too often bar those with disabilities from participating fully in the Nation's life, including the workplace. ${ }^{167}$ Further, Breyer continued, these objectives "will

164. Barnett, $122 \mathrm{~S}$. Ct. at 1521 . Under the ADA, to obtain the "same workplace opportunities that those without disabilities automatically enjoy," those with disabilities are guaranteed "reasonable accommodation" preferences. Id.

165. Zelman v. Simmons-Harris, 122 S. Ct. 2460 (2002). For example, Rehnquist claimed that the aid plan is "neutral in all respects" and "entirely neutral." Id. at 2467, 2473. The second main prong of the majority's analysis involved its repeated assertion that the aid recipients - the parents participating in the voucher program-could make "true private choices," thereby adequately insulating aid to religious institutions from state involvement. Id. at 2466-68.

166. See, e.g., id. at 2485 (Souter, J., dissenting).

167. Barnett, 122 S. Ct. at 1522-23. 
sometimes require affirmative conduct to promote entry of disabled people into the workforce. ${ }^{\text {"168 }}$ Following the "practical way" that many lower courts have tried to reconcile the burdens of "reasonable accommodation" and "undue hardship," the Court described a litigation process. To defeat a summary judgment motion, a plaintiff/employee need only show that an accommodation seems reasonable on its face. If a plaintiff can make this showing, then the defendant/employer must show "special (typically case-specific) circumstances that demonstrate undue hardship in the particular circumstances. ${ }^{n 169}$ Ironically, however, in applying this new test, the plurality went on to hold that an accommodation that interferes with an existing seniority system is, by definition, "ordinarily" not "reasonable." "170

Breyer's enthusiasm for what he described as the predictability and relative fairness of seniority systems-even when imposed by the employer-points to a neutrality concern at another level, again involving deeply controversial but also basic issues. ${ }^{171}$ There seems

168. Id. at 1523. He added, perhaps unnecessarily (or perhaps as his response to Souter's dissent), "(t)hey do not, however, demand action beyond the realm of the reasonable." Id. Just before, Breyer had insisted that "reasonable" did not mean "effective," but he went on to assert that, in "ordinary English," "accommodation" does convey the need for effectiveness. Id. at 1522 .

169. Id. at 1523. This procedure echoes that used in Title VII, and it is an echo that makes considerable sense in the ADA context, though it unfortunately has not been much followed. See Silvers \& Stein, supra note 134, at 123-24.

170. Barnett, $122 \mathrm{~S}$. Ct. at 1524. In emphasizing the advantages of seniority systems, Breyer relied on lower court cases construing collectively bargained seniority systems, but he extended his deference to unilaterally imposed seniority systems as well. Id. Claiming a number of "relevant seniority system advantages," the plurality then returned the burden to the plaintiff/employee to show "special circumstances" weighty enough to make any proposed exception to an existing seniority system a "reasonable accommodation" under the particular circumstances of the case. Id. at 1524-25.

171. Even when ADA claimants manage to eke out some extremely narrow protection from the Supreme Court, however, they seem to be left with a very heavy practical burden to meet. In Cleveland v. Policy Management Systems Corp., 526 U.S. 795 (1999), for example, Justice Breyer's unanimous opinion allowed a person who claimed to be completely disabled from working for purposes of Social Security Disability Income (SSDI) to claim later that she was capable of working for purposes of the ADA. As Anita Silvers and Michael Stein have explained, however, the Court actually mixed factual and legal inquiries and managed to create a "stipulation of counterfactual coextensivity ...." Silvers \& Stein, supra note 134, at 131; see also Anita Silvers \& Michael Stein, From Plessy (1896) and Goesart (1948) to Cleburne (1985) and Garrett (2001): A Chill Wind From the Past Blows Equal Protection

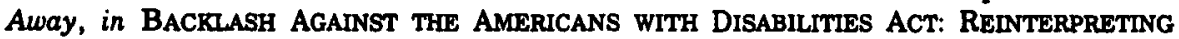
DISABILITY RIGHTS (Linda Hamilton Krieger ed., 2002). 
to be something about the ADA, however, that permits the Court to ignore some of its own leading analogous precedents.

In Wygant v. Jackson Board of Education, ${ }^{172}$ for example, a divided Court struck down a collectively bargained plan governing school layoffs. The union had voted repeatedly to modify a straight seniority plan so that minority teachers would not be laid off as quickly as white teachers, and the school board agreed to the plan. In striking down this arrangement as a racial classification that was invalid on equal protection grounds, Justice Powell's plurality opinion stressed the vital importance of keeping a job. ${ }^{173}$ In this sense, Wygant seems to support Barnett's deep commitment to seniority systems of all kinds, but it also seems to disagree with Toyota's denigration of the importance of working. Yet Powell also expressed concern that more senior union members were likely to support a plan that would not directly affect them, and he conceded that seniority systems could be modified in the interest of fairness. ${ }^{174}$ Indeed, even Wygant's emphatic disagreement with the use of racial classifications to advance "affirmative action" goals without a sufficient factual predicate indicated that the result would be different if the relevant employer had a demonstrated history of past discrimination. In passing the $A D A$, Congress specifically found extensive evidence of past discrimination against people with disabilities. ${ }^{175}$

It is well past time for the Court to acknowledge the patterns and practices of past discrimination by employers against people with disabilities. Barnett's ready acceptance of seniority-absent special

172. 476 U.S. 267 (1986).

173.

Even a temporary layoff may have adverse financial as well as psychological effects. A worker may invest many productive years in one job and one city with the expectation of earning the stability and security of seniority. 'At that point, the rights and expectations surrounding seniority make up what is probably the most valuable capital asset that the worker "owns," worth even more than the current equity in his home.... Layoffs disrupt these settled expectations in a way that general hiring goals do not.

Id. at 283 (quoting Fallon \& Weiler, Conflicting Models of Racial Justice, 1984 SUP. CT. REv. 1,58 ).

174. Id. at 282.

175. See, e.g., 42 U.S.C. $\& 12101(a) 5$, $\& 12101(a) 7, \S 12101$ (a)(9) (2000). These sections prompted Congress' statement of the ADA's purpose as "a categorical antidiscrimination directive by the federal government on behalf of disabled Americans." Silvers \& Stein, supra note 134 , at 113 . 
circumstances-seems to invite litigation to demonstrate such special circumstances. The kicker, however, is that workplace discrimination against persons with disabilities remains pervasive. A proven history of employment discrimination, therefore, could be dismissed by the current Court with a classic Catch-22 argument, i.e., that such a pattern does not constitute a "special circumstance" at all. Justice Scalia's dissent in Barnett accused the plurality of "[i]ndulging its penchant for eschewing clear rules that might avoid litigation. ${ }^{.176}$ Of course, "the disabled plaintiff will lose" is a clear rule.

3. Chevron, U.S.A., Inc. v. Echazabal: ${ }^{177}$ Workplace Paternalism and a Specifically Demonstrated Risk

In Echazabal, the Court again unanimously reversed a court of appeals decision, this time because the Ninth Circuit questioned the authority of the Equal Employment Opportunity Commission (EEOC) to promulgate a regulation under the ADA allowing an employer to refuse to hire an individual if, due to disability, the individual's job performance might pose a direct threat to his own health. Mario Echazabal worked for an independent contractor in a Chevron oil refinery beginning in 1972 . His legal troubles began, however, when he twice attempted to work directly for Chevron. The first time Echazabal was offered a job by Chevron, he failed a required physical examination due to a liver abnormality. Echazabal continued to work for the independent contractor, however, and his duties continued to take him into the section of the refinery believed to be most dangerous to someone with his liver condition. When Echazabal tried to work directly for Chevron a second time, he again was offered a job if he could pass the physical. Again he failed, and this time Chevron instructed Echazabal's employer to reassign him or to remove him from the plant. Echazabal soon was laid off and filed suit in state court claiming, among other things, that Chevron had violated the ADA. ${ }^{178}$

176. Barnett, 122 S. Ct. at 1528 (Scalia, J., dissenting).

177. 122 S. Ct. 2045 (2002).

178. Id. at 2047-48. Chevron removed the case to federal court and insisted that Echazabal's health problem, which ultimately had been diagnosed as Hepatitis C, made the job he sought a direct threat to his health. The company relied on an EEOC regulation, 29 
Justice Souter's unanimous opinion unpacked the ADA's affirmative defense of "business necessity." defense as "a requirement that an individual shall not pose a direct threat to the health or safety of other individuals in the workplace." ${ }^{180}$ Souter made a strong case, however, that it was plausible for the EEOC to extend the defense to threats to oneself, as well as to others not in the workplace. ${ }^{181}$

Most significantly for our purposes, the Court also sought to distinguish between the ADA's clear rejection of "workplace paternalism"182 and the individualized inquiry into "specific and documented risks to the employee himself ${ }^{183}$ that the Court found permissible under the ADA. Yet drawing a line between acceptable and unacceptable paternalism is deeply problematic, ${ }^{184}$ as is defining acceptable "individualized risk assessments."

The Court attempted to distinguish Title VII gender cases in which the Court rejected company rules that purported to protect

C.F.R. $\& 1630.15(b)(2)(2001)$, for its claim that a direct threat to an employee's own health would suffice as an ADA defense. See Echazabal, 122 S. Ct. at 2047-48.

179. 42 U.S.C. $\$ 12113$ (a) (2000); id. \& 12112 (b)(6).

180. Id. § 12113(b).

181. Souter specifically listed three strikes against Echazabal's claim. First, he argued that the statute stated an example, rather than a list, so that the canon "expressio unius exclusio alterius,' 'expressing one item of [an] associated group or series excludes another left unmentioned," did not apply. Echazabal, $122 \mathrm{~S}$. Ct. at 2049. Second, he rejected the idea that the omission could be attributed to unequivocal congressional intent. He specifically referred to interpretations of the Rehabilitation Act that he claimed Congress intended to adopt in the ADA. Id. at 2050. Third, mentioning Typhoid Mary, he argued that Congress could not have meant to allow a worker's disability to threaten others not in the workplace. Id. at 2051.

182. Id. at 2053. Souter approvingly summarized the EEOC's interpretation of the ADA's policy aimed at employers' "refusals to give an even break to classes of disabled people, while claiming to act for their own good in reliance on untested and pretextual stereotypes." Id. at 2052. He also described Congress' policy as providing "a disabled individual's right to operate on equal terms within the workplace." Id.

183. Id. at 2053. Actually there was a significant dispute about Echazabal's medical condition. See infra text accompanying note 192. The record also suggests some doubt about whether Chevron acted entirely out of benevolent paternalism. For example, the company continued to allow Echazabal to do work for an independent contractor in its refinery after a company doctor rejected Echazabal for a job with Chevron on medical grounds, and Chevron even offered him the job a second time, if he could pass the physical exam.

184. It has been troublesome for a long time, and played a crucial role during the heyday of the Court's interventions against government regulations on behalf of "liberty of contract." See Aviam Soifer, The Paradax of Paternalism and Laissez-Faire Constitutionalism: United States Supreme Court, 1888-1921, 5 L. \& HIST. REv. 249 (1987). 
women and potential fetuses. ${ }^{185}$ Souter claimed that excluding women from jobs deemed too risky was different and "beside the point," because those policies "were concerned with paternalistic judgments based on the broad category of gender ...."186 But the decisions he cited also turned on the importance of allowing each individual employee to assess risk for herself. ${ }^{187}$ "[W]omen as capable of doing their jobs as their male counterparts may not be forced to choose" based on risk to themselves or their fetuses. ${ }^{188}$ Why are the rules different for a person with a disability who is as capable of doing the job as a nondisabled person, except for some notion of paternalism?

The Court's reliance on a "particularized enquiry into the harms the employee would probably face ${ }^{189}$ and its other statements stressing "individualized assessment" ${ }^{\not 190}$ might resolve some doubts. By now we know that the Court is willing to accept sweeping generalizations-such as vague assumptions about what is "of central importance to most people's daily lives" - as the measure in an individualized assessment. ${ }^{191}$ (After Toyota, it also is not clear why the Court seemed simply to assume that Echazabal fit the Court's definition of "disability" in the context of employment). In reversing the Ninth Circuit, moreover, and remanding without

185. Echazabal, $122 \mathrm{~S}$. Ct. at 2053 n.6. The two cases cited were Automobile Workers v. Johnson Controls, Inc., 499 U.S. 187, 202 (1991) and Dothard v. Rawlinson, 433 U.S. 321,335 (1977). See Silvers \& Stein, supra note 134, for an insightful discussion of the overlap between the Court's older approach to gender bias, symbolized by Goesaert v. Cleary, 335 U.S. 464 (1948), and its current approach to disability issues. This article directly anticipated many of the pitfalls the Court failed to notice in Echazabal.

186. Echazabal, 122 S. Ct. at 2053 n.5.

187. After asserting that "the purpose of Title VII [is] to allow the individual woman to make that choice [the acceptability of risk in a particular job] for herself," Dothard actually upheld a gender restriction based on the claim that requiring prison guards to be male was a bona fide occupational qualification. Dothard, 433 U.S. at 335. And Johnson Controls also emphasized individual choice repeatedly in the course of striking down the employer's "fetal protection plan." Johnson Controls, 499 U.S. at 207. For example, Justice Blackmun's majority opinion stressed that "[d]ecisions about the welfare of future children must be left to the parents who conceive, bear, support, and raise them rather than to the employers who hire those parents." Id. Justice Blackmun read the Pregnancy Discrimination Act to require that "the decision to become pregnant or to work while being either pregnant or capable of becoming pregnant was reserved for each individual woman to make for herself." Id.

188. Johnson Controls, 499 U.S. at 204.

189. Echazabal, 122 S. Ct. at 2053.

190. Id.

191. See discussion supra notes $140-58$ and accompanying text. 
additional instructions, the Court accepted the district court's grant of summary judgment. The district court, however, had decided the matter despite the

two medical witnesses [who] disputed Chevron's judgment that Echazabal's liver function was impaired and subject to further damage under the job conditions in the refinery ... that Echazabal raised no genuine issue of material fact as to whether the company acted reasonably in relying on its own doctors' medical advice, regardless of its accuracy. ${ }^{192}$

Echazabal thus offers a sobering paradigm for what constitutes an "individualized risk assessment." It is: employer knows best. Even if inaccurate, his judgment will be accepted. The Court thus seemed to accept just the kind of broad paternalistic judgments it tried to distinguish in Echazabal.

\section{Play (and Some Dire Consequences)}

Jeffrey Gorman managed to get into a fight with a bouncer in a Kansas City nightclub, and it appears he lost. Police then arrested him on trespass charges. Gorman, a paraplegic and a wheelchair user who did not have voluntary control of his lower torso, needed a catheter attached to a urine bag. The police van was not equipped to handle a wheelchair. A series of painful, harmful, and embarrassing mistakes ensued, including the rupturing of Gorman's urine bag and an injury to his shoulder and back, as a police officer transported Gorman to the police station. Gorman suffered serious medical problems, and was no longer able to work full time. He sued Kansas City police officials and officers, claiming they had discriminated against him in violation of the $A D A$ and the Rehabilitation Act ${ }^{193}$ A jury awarded Gorman more than $\$ 1$ million in compensatory damages and $\$ 1.2$ million in punitive damages. The district court vacated the punitive damages award, but the Eighth Circuit reversed, holding that punitive damages are available under the two statutes. ${ }^{194}$

192. Echazabal, 122 S. Ct. at 2048.

193. Barnes v. Gorman, 122 S. Ct. 2097, 2099-100 (2002).

194. Id. at 2100. 
The Court reversed, emphasizing the Spending Power link between federal norms and Kansas City's receipt of federal funds. Justice Scalia's opinion for the Court involved a series of analogies and concluded that "appropriate relief" in a discrimination suit against a public entity under the ADA does not include punitive damages. ${ }^{195}$ The key, according to Scalia, was that if Congress uses its Spending Power to impose conditions on state and local governments, those conditions are to be considered in the nature of a contract. ${ }^{196}$ Thus, the Court held, such conditions must be unambiguous. The acceptance by the state or locality has to be clearly knowing and voluntary. ${ }^{197}$

Scalia, extending the contract analogy, held that Kansas City was not clearly on notice of potential liability for punitive damages. Therefore, the jury's punitive damages award could not be upheld. ${ }^{198}$

195. Id. at 2100-03. The relevant section of the ADA, 42 U.S.C. $\$ 12133(2000)$, refers to the Rehabilitation Act's remedial provision, 29 U.S.C. $8794 \mathrm{a}(\mathrm{a})(2)(2000)$, which in turn refers to Title VI of the Civil Rights Act of 1964, 42 U.S.C. $\$ 82000$ e-2000e-17. Though Title VI long ago was held to imply a private cause of action, Cannon v. University of Chicago, 441 U.S. 677 (1979), the Court has been chopping away at the effectiveness of such lawsuits. See, e.g., Alexander v. Sandoval, 532 U.S. 275 (2001) (holding that Title VI did not allow a private lawsuit challenging disparate-impact discrimination, thereby allowing Alabama to differentiate in drivers' license tests, for example, between people illiterate in English, for whom accommodation was available, and those illiterate in other languages, who were not allowed to take the test).

196. Barnes, 122 S. Ct. at $2100-01$.

197. Id. at 2101. The Court's expression of great concern about how knowing and voluntary the consent by these government entities must have been contrasts with its frequent refusal to scrutinize the knowing and voluntary quality of consent by those who tend to have less legal advice and to be less sophisticated See, e.g., Dep't of Hous. \& Urban Dev. v. Rucker, 122 S. Ct. 1230 (2002) (upholding expulsion of grandmothers, for example, from public housing because of drug use by their grandchildren outside the housing area, emphasizing that the grandmothers had signed leases long before that permitted such a remedy against them).

198. Barnes, $122 \mathrm{~S}$. Ct. at 2101-02. Because no implicit consent could be discovered within traditional contract law terms, the Court believed it followed that Kansas City did not consent to punitive damages liability, and would not have done so. Scalia emphasized the economic nature of remedies for third-party beneficiaries in the Spending Power context, and made no mention of the dignitary harms that tend to accompany being the victim of official discriminatory conduct. Id. at 2102. There is thus a dramatic contrast to the Court's recent aggressive interventions in the name of the dignity of the states. See, e.g., Fed. Mar. Comm'n v. S.C. State Ports Auth., 122 S. Ct. 1864, 1874 (2002). Scalia's decision to reverse the jury's decision also suggests somewhat less faith in the legal acumen of Kansas City residents than Scalia proclaimed when he argued that "nine people picked at random from the Kansas City telephone directory" were just as qualified as the Justices to make determinations about continuing life-support for a person in a persistent vegetative state. Cruzan v. Dir., Mo. Dep't of Health, 497 U.S. 261, 293 (1990) (Scalia, J., concurring). 
Once again, individualized assessment under the ADA turned out to be complicated. Congress' central concern with discrimination in passing the ADA again carried little weight with the Court. The Court also returned to the Garrett theme of protecting local government from its citizens.

\section{TO TREAT UNLIKE CASES ACCORDINGLY: The DILEMMa OF DIFFERENCE AND THE GUARANTEE OF FULL AND EQUAL OPPORTUNITIES}

\section{A. A Vessel for All Seekers}

From our personal lives, we know that at times it is crucial to treat all family members the same, but at times it is essential to treat each family member differently. The "dilemma of difference," compellingly described and analyzed by Martha Minow, ${ }^{199}$ pervades societal judgments as well. Paradoxically, as Minow put it:

The stigma of difference may be recreated both by ignoring and by focusing on it.

....

... The dilemma of difference grows from the ways in which this society assigns individuals to categories and, on that basis, determines whom to include in and whom to exclude from political, social, and economic activities. ${ }^{200}$

Sometimes, in fact, treating everyone the same way can be so wrongheaded as to be fatal. A chilling example occurred in the immediate wake of World War II. According to official State

Justice Stevens, joined by Justices Ginsburg and Breyer, concurred only in the Barnes result. Stevens suggested that there were far narrower grounds to reject the punitive damages award; he would have relied on City of Newport v. Fact Concerts, Inc., 453 U.S. 247 (1981) (holding that municipalities are not subject to punitive damages absent clear contrary congressional intent). Stevens questioned the relevance of the contract analogy for a claim of tortious action, and expressed concern about the potentially far-reaching and unforeseen consequences of the broad theory embraced by the "fearless crusaders" who joined the Court's opinion. Barnes, 122 S. Ct. at 2104-05 n.3. Scalia responded to what he dubbed Stevens' "Chicken-Little statement" by sarcastically claiming that "we surely do not deserve his praise that we are fearless crusaders. ${ }^{m} I d$. at 2102 n.2.

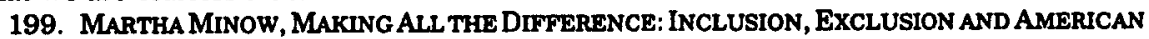
LAW (1990).

200. Id. at 20-21. 
Department policy, all displaced persons had to be treated equally: the same repatriation policy, the same exercise regimen, and the same diet. The survivors of the extermination camps and their former guards, therefore, were housed together and treated exactly the same, with fatal results. ${ }^{201}$

Some of the Supreme Court's most vital constitutional holdings over the past fifty years turn on the basic recognition that "[e]qual protection of the laws is not achieved through indiscriminate imposition of inequalities. ${ }^{\text {2202 }}$ As Chief Justice Rehnquist recently wrote for the Court, the Equal Protection Clause "embodies a general rule that States must treat like cases alike but may treat unlike cases accordingly. ${ }^{\text {203 }}$ Finally, the Court recognized decades ago that "community prejudices are not static, and from time to time other differences from the community norm may define other groups which need the same protection" from the Court as do racial minorities. ${ }^{204}$ The "protection" part of equal protection at times requires careful scrutiny of treatment that, at least on the surface, appears to be equal.

Until recently, moreover, it seemed clear that Congress had expansive power to enforce civil rights with whatever civil and even criminal remedies it thought might be effective. Thirty years ago, for example, Chief Justice Burger wrote enthusiastically for a unanimous Court that Title VII of the Civil Rights Act of 1964 "proscribes not only overt discrimination but also practices that are

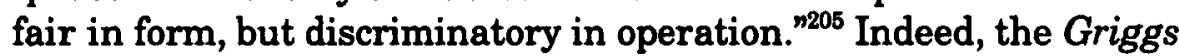

201. See Yosef Dov Shenson, A SURvivorS' HaGgadAH xiv-zv, 76-77 (Saul Touster ed., 1998).

202. Shelley v. Kraemer, 334 U.S. 1, 22 (1948); see also Loving v. Virginia, 388 U.S. 1, 9 (1967) (recognizing that the "fact of equal application does not immunize [Virginia's antimiscegenation] statute" from very heavy burden of justification required of racial classifications).

203. Vacco v. Quill, 521 U.S. 793, 799 (1997).

204. Hernandez v. Texas, 347 U.S. 475, 478 (1954) (invalidating jury selection process with effect of excluding Mexican Americans). Hernandez was a unanimous decision written by Chief Justice Warren and handed down two weeks prior to Brown $v$. Board of Education, 347 U.S. 483 (1954).

205. Griggs v. Duke Power Co., 401 U.S. 424, 431 (1971) (invalidating "built-in headwinds" imposed by company's seemingly neutral job requirements; the vote was eight-to-zero, with Justice Brennan not participating). Jacobus ten Broek provided a pioneering argument for a higher duty of care for people with disabilities in the context of tort law in Jacobus ten Broek, The Right to Live in the World: The Disabled in the Law of Torts, 54 CAL. L. REv. 841 (1966). See generally Michael Ashley Stein, Labor Markets, Rationality, and Workers with 
Court invoked "the fabled offer of milk to the stork and the fox," in which the more powerful fox cannot drink from a long, thin jug at all. $^{206}$ The Court declared itself bound to follow Congress' decision that "the vessel in which the milk is proffered be one all seekers can use." 207

This fable seems more apt to the situations of many people with disabilities who invoke the ADA's public accommodation protections than does the series of analogies proposed by Judge Posner and embraced by Justice Scalia. The Griggs Court's sense of legislative power to seek change through increased efforts to guarantee civil rights is directly apropos of the ADA. Yet a majority of the current Justices are extremely dubious about any room for Congress between the market and the Court's own constitutional holdings. In many situations, Congress may not expand civil rights beyond the territory where the Court itself already has gone. If this trend has not yet taken the form of massive constitutional invalidationsthough the Court is already doing such things when the states themselves are involved ${ }^{208}$ - the Court's miserly reading of the ADA illustrates some of the myriad of other methods available to activist judges bent on construing a broad civil rights statute nearly to oblivion.

In a sad echo of the Court's own role in aiding and abetting the rise of Jim Crow in the Reconstruction Era, which culminated in Plessy v. Ferguson ${ }^{209}$ and its progeny, the Court today again insists on its own authority to interpose a protective cordon around a broad enclave of social and commercial matters. Congress may not intrude into this sanctuary for private ordering, even in the name of civil rights. ${ }^{210}$ Indeed, deference to private ordering reaches to the contact zone of the deference required by the essentials of state sovereignty. For the Court today, no middle ground can be sustained.

Disabilities, 21 BERKGLEY J. EMP. \& LAB. L. 314 (2000).

206. Griggs, 401 U.S. at 431.

207. Id.

208. See, e.g., United States v. Morrison, 529 U.S. 598 (2000); Alden v. Maine, 527 U.S. 706 (1999); Printz v. United States, 521 U.S. 898 (1997), and discussion of Garrett regarding New Federalism, supra, at 19-26.

209. 163 U.S. 537 (1896).

210. For one of the many critical discussions of the Court's interposition of its New Federalism beliefs, see Soifer, supre note 14, at 1321-28. 


\section{B. Public Accommodation: Moving the Middle Ground}

But there is middle ground. A great deal of it, in fact. It is where we really live our lives. The intertwining of our better angels and our baser selves is probably the universal human condition. We are all individuals; we are all members of a multitude of groups. Each of us is full of change, compromise, and various abilities-and then we change again.

It must be conceded, however, that both judicial and statutory law involve drawing lines and making decisions intended to reach beyond individual cases on the day they are handed down. Yet even in law there is and ought to be a great deal of nonbinary middle ground.

One prime example of important middle ground-directly relevant to our consideration of $\mathrm{ADA}$ issues-is the realm of public accommodations. Public accommodations have been neither entirely private nor entirely public for centuries; there is, for example, a strong common law tradition obliging those who own and run public accommodations to serve even those who are outsiders or otherwise different somehow. ${ }^{211}$

After all, despite its appalling shortsightedness, even the Civil Rights Cases decision simply assumed that law at the state level obliged innkeepers, people operating public transportation, and similar ventures to serve the general public. ${ }^{212}$ In dissent, the first Justice Harlan presciently made the point that Congress surely had the power to regulate such quasi-public entities, and that terrible things would follow from the majority's crabbed view of the Thirteenth and Fourteenth Amendments. Harlan thus built upon the majority's sense of obligatory public accommodations law. ${ }^{213}$

The current Court, of course, has embraced the Civil Rights Cases as a key precedent pointing the way to constitutional limitations on

211. Joseph William Singer, No Right to Exclude: Public Accommodations and Private Property, 90 Nw. U. L. REv. 1283, 1291-93 (1996).

212. Civil Rights Cases, 109 U.S. 3, 19, 24-25 (1883) (assuming "a right to enjoy equal accommodation and privileges" to be an essential right, but insisting that remedial authority must be left to the states).

213. Id. at $37-48$ (Harlan, J., dissenting) (discussing denial of equal accommodations in public conveyances, inns, and places of public amusement as denial of basic civil rights and as badge of servitude). 
Congress' civil rights enforcement power. ${ }^{214}$ Today's Justices have made it clear that they do not approve of broad state protections for public accommodations. In Boy Scouts of America v. Dale ${ }^{215}$ for example, Chief Justice Rehnquist bemoaned the extensive reach of the New Jersey statute that, according to the New Jersey Supreme Court, required the Boy Scouts not to discriminate on the basis of sexual orientation. ${ }^{216}$ But even so, public accommodations law continues to change and adjust to better understood (or even newly recognized) forms of unacceptable discriminatory activity. ${ }^{217}$

The ADA lists twelve categories of public accommodations, thereby broadening the range of quasi-public and quasi-private territory in which private discrimination may not go unnoticed. Private discrimination, moreover, can even take the form of equal treatment. Echoing federal civil rights statutes stretching back to 1866, the ADA's guarantees are for "full" as well as for "equal" enjoyment of whatever is offered by these public accommodations to the general public. ${ }^{218} \mathrm{My}$ suggestion, in keeping with the general rules of statutory interpretation, is that "full" ought not to be considered surplusage or redundant with "equal." Indeed, a guarantee of full and equal rights, benefits, privileges, and so forth points directly to evaluations on a case-by-case basis. This approach is particularly needed when the equal treatment of non-similarlysituated people penalizes or stigmatizes some individuals beneath the cloak of treating everyone alike.

214. Ironically, if one were to use the current Court's approach which severely limits the power of Congress to invoke Section Five of the Fourteenth Amendment, it is not even clear that Congress constitutionally could depart from the holding of Dred Scott $v$. Sandford, 60 U.S. 393 (1856) in its significant array of civil rights statutes passed from 1866-1875. See generally Ruth Colker \& James J. Brudney, Dissing Congress, 100 MiCH. L. REv. 80 (2001); Robert C. Post \& Reva B. Siegel, Equal Protection by Law: Federal Antidiscrimination Legislation After Morrison and Kimel, 110 YALE L.J. 441 (2000); Aviam Soifer, Full and Equal Rights of Conscience, 22 U. HAw. L. REv. 469, 484-92 (2000).

215. 530 U.S. $640(2000)$.

216. Id. at 656-57. The Court also strongly disagreed with a state court's interpretation of its state public accommodation law in Hurley v. Irish-American Gay, Lesbian and Bisexual Group of Boston, 515 U.S. 557 (1995) (unanimously holding that requiring private citizens to provide access to their St. Patrick's Day Parade for a group whose message the parade organizers found repugnant is unconstitutional).

217. Nan D. Hunter, Accommodating the Public Sphere: Beyond the Market Model, 85 MrNN. L. REV. 1591, 1613-29 (2001).

218. 42 U.S.C. $\$ 12182(\mathrm{a})(2000)$; Civil Rights Act of 1866, ch. 31 § 1, 14 Stat. 27 (1866). 


\section{Full and Equal Guarantees}

Many people currently seem to embrace the struggle of each against all as if humanity were back in a state of nature. Competition and private ordering certainly have reached the marble halls of the Supreme Court. What is often missed, however, is that even John Locke-often portrayed as the patron saint of individualistic striving - claimed that mankind abandoned the state of nature specifically to gain protection from the state. ${ }^{219}$

Reciprocal obligations of allegiance and protection, linking citizens and the state, constituted a major motif in eighteenth- and nineteenth-century American political thought. This point helps explain why it then was more generally acceptable than it is today for government to foster economic growth and to regulate private ordering for the public good. ${ }^{220}$ It also underscores a claim made by Justice Holmes, rejecting his colleagues' enthusiasm for the liberty of contract. Holmes vigorously dissented, for example, when the majority in Coppage v. Kansas ${ }^{221}$ struck down an attempt by the state legislature to protect workers from being coerced into "yellow dog" contracts, through which employees had to renounce any union membership. He wrote that the state could intervene to "establish the equality of position between the parties in which liberty of contract begins. ${ }^{222}$ For the Coppage majority, however, Justice Pitney proclaimed it is "from the nature of things impossible to uphold freedom of contract and the right of private property without at the same time recognizing as legitimate those inequalities of fortune that are the necessary result of the exercise of those rights. ${ }^{\text {"223 }}$ Public accommodations law usefully can be viewed as an

219. See Carlos A. Ball, Autonomy, Justice, and Disability, 47 UCLA L. REv. 599, 606-15 (2000).

220. See, e.g. OSCAR HANDLIN \& MARY F. HANDLIN, COMmONWEALTH: A STUdY OF THE ROLE OF GOVERNMENT IN THE AMERICAN ECONOMY: MASSACHUSETTS, 1774-1861 (1947); WILLAMJ.

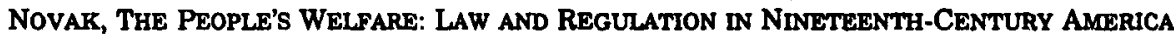
(1996); Leonard W. Levy, The Police Power, in THE LAW Of THE COMmonwEALTH aNd ChIEF JUSTICE SHAW 229-65 (1957).

221. 236 U.S. 1 (1915).

222. Id. at 27 (Holmes, J., dissenting); see also West Coast Hotel Co. v. Parrish, 300 U.S. 379, 399-400 (1937) ("The community is not bound to provide what is in effect a subsidy for unconscionable employers. The community may direct its law-making power to correct the abuse which springs from their selfish disregard of the public interest.").

223. Coppage, 236 U.S. at 17. 
example of the democratic process seeking to split the difference between these two positions.

An example from history is illuminating: Ollie's Barbecue in Birmingham, Alabama certainly had business reasons as well as constitutional claims of freedom from forced association and federalism to defend its racial exclusion policies. Yet it did not matter to the Supreme Court that Ollie's employed black people, nor that black customers could buy barbecue "to go" at the take-out counter. ${ }^{224}$ Nor would the Court have been likely to find Title II, the public accommodations section of the 1964 Civil Rights Act, satisfied if Ollie's owners had responded to outside government pressure and let black people sit in the restaurant, but then placed a cap on their portion size. Like the ADA's public accommodation provision considered in the Martin context, Title II of the 1964 Civil Rights Act guarantees "full and equal" access and service. ${ }^{225}$ It thus contains the potential for standardless federal judicial oversight of the size of portions or the relative quality of the cuts of meat. Nonetheless, in the face of vehement resistance, Title II made and continues to make a difference without tying the courts in knots. It deals with meals enjoyed as well as with the unquantifiable dignity of those who, through the new protection of federal civil rights laws, could get into places of public accommodation and not be penalized, mistreated, or neglected once present at the table as fully equal customers.

\section{Standardless Judgments and the Judicial Role: Protection}

To take the "full" part of "full and equal" seriously is to concede that many cases will be difficult. The ADA itself provides that only reasonable accommodations will be required, and then only if these accommodations do not fundamentally alter the service or product at issue. ${ }^{226}$ This kind of decision making is familiar in both our private and our public law. The common law tradition famously builds case-by-case, of course, but so does much of constitutional law. The development of the regulatory takings doctrine, embraced

224. Katzenbach v. McClung, 379 U.S. 294 (1964).

225. 42 U.S.C. $\$ 2000 \mathrm{a}(\mathrm{b})(2000)$.

226. Id. \&12182(b)(2)(A)(iii). 
by the same Justices who seem most keen to rely on essences in the realm of discrimination law, may serve as a good example.

From its start in an opinion by Justice Holmes in the 1920s, the doctrine of regulatory takings has been said to be a question of degree ${ }^{227}$ Unless all economic value is destroyed, today a property owner who pursues a regulatory takings claim will find her situation judged in terms of relative economic impact, her particular investment-backed expectations, and the government interest at stake in the challenged legal action. ${ }^{228}$ Moreover, even if the challenged law was invalidated, or if it already was in place when the property owner took title, ${ }^{229}$ she still can come to court to claim she was wronged.

At first glance, the regulatory takings plaintiff may not seem to afford a paradigmatic case for a person with disabilities who claims protection under the ADA. But neither kind of claim is categorical, and both potentially involve courts in nitty-gritty, fact-dependent inquiries. More significantly, both the takings claimant and the person with disabilities may find legal relief for being treated differently from the rest of society. Each would like to be protected in the full and equal enjoyment of something important. In both cases, moreover, the impact of a facially neutral decision may intrude on the individual's specific situation so directly, grossly, or arbitrarily as to demand legal redress. ${ }^{230}$

What the disabled person has that the property owner lacks, however, is individual membership in a group found by Congress to be

a discrete and insular minority who have been faced with restrictions and limitations, subjected to a history of purposeful unequal treatment, and relegated to a position of political powerlessness in our society, based on characteristics that are

227. Pa. Coal Co. v. Mahon, 260 U.S. 393, 416 (1922).

228. Penn Cent. Transp. Co. v. New York City, 438 U.S. 104 (1978).

229. Palazzolo v. Rhode Island, 533 U.S. 606 (2001) (finding a taking despite the fact that the regulation was imposed before the owner's acquisition of the property); First English Evangelical Lutheran Church v. County of Los Angeles, 482 U.S. 304 (1987) (finding damages were required for temporary period when taking was in effect).

230. Vill. of Willowbrook v. Olech, 528 U.S. 562, 565 (2000) (finding "irrational and wholly arbitrary" demand and actions by Village sufficient to state traditional equal protection claim). 
beyond the control of such individuals and resulting from stereotypic assumptions not truly indicative of the individual ability of such individuals to participate in, and contribute to, society. ${ }^{231}$

Past discrimination is surely relevant in a remedial statutory scheme.

Our judges, after insisting on individualized judgments in construing the $\mathrm{ADA},{ }^{232}$ ought not impose the burdens of hostile and arbitrary individualized judgments against ADA claimants. Indeed, the essence of legal protection in court is anchored in the effort to provide an adequate, as well as an equal, hearing to every claim, and to strive to vindicate fully the rights of those for whom equal treatment requires special attention and even, at times, reasonable accommodation.

A recent First Circuit decision provides an excellent example, directly contrasting with the Court's markedly parsimonious approach to the ADA. Could Kelly Gillen, a young woman born with a left arm that ends a few inches below her elbow, be employed as an Emergency Medical Technician (EMT)? Fallon Ambulance Service rejected Gillen, though she had "performed impeccably in a myriad of jobs." ${ }^{\text {233 }}$ Relying in part on a doctor's opinion, the ambulance service argued that two-handed lifting was one of the "essential functions" of the job. ${ }^{234}$ Judge Selya's opinion carefully outlined the appropriate procedural framework when an ADA claim is met with a summary judgment motion, and stated that the key is "to distinguish between unfounded stereotypes, on the one hand, and frank assessments of the actual consequences of a disability, on the

231. 42 U.S.C. \& 12101(a)(7).

232. See Soifer, supra note 14, at 1299-1312.

233. Gillen v. Fallon Ambulance Serv., Inc., 283 F.3d 11, 17 (1st Cir. 2002).

234. Id. Both the ADA, 42 U.S.C. ₹ 12111(8) (2000), and EEOC regulations describe the need for an applicant to be able to perform the "essential functions" of a job, and both mention some kinds of evidence that might establish what those functions entail. As Judge Selya explained: "The purpose of these provisions is not to enable courts to second-guess legitimate business judgments, but, rather, to ensure that an employer's asserted requirements are solidly anchored in the realities of the workplace, not constructed out of whole cloth." Gillen, 283 F.3d at 25. Recognizing that "the line between an essential function that seems at first blush to be self-evident and a marginal function is sometimes blurred," id. at 28, the First Circuit carefully considered, for example, how long, under what circumstances, and how consistently the employer had maintained that "two-handed lifting" was essential. 
other hand. ${ }^{235}$ Gillen, in fact, had been certified as an EMT, and she already was employed as an EMT by another company. She also had undertaken a weight-lifting regimen and had successfully demonstrated her ability to lift the amount of weight the employer declared necessary to do the job. ${ }^{236}$ Judge Selya argued that summary judgment was therefore not appropriate based on the record before the district court. After all, one of the primary goals of the ADA is "to prohibit employers from making adverse employment decisions based on stereotypes and generalizations associated with the individual's disability rather than on the individual's actual characteristics. ${ }^{237}$

This does not mean, of course, that every access or accommodation claim should succeed. If people in wheelchairs probably ought to gain access to the floating craps tables as well as to the bathroom aboard the Casino Princesa, ${ }^{238}$ it does not follow that a belated request for a special access ticket to a sold-out professional sports event must be honored. ${ }^{239}$ Nor does the Martin case mean that a racquetball player in a wheelchair is entitled to an extra bounce in a club tournament. ${ }^{240}$ But there is not and should not be any essentialist answer to the knotty, daily issues that arise as we try to give full meaning to full and equal civil rights for everyone.

\section{CONCLUSION}

The term "accommodate" originally meant "suited," "adapted," or "fitting" and, in 1769, one Sir J. Reynolds wrote: "The regular progress of cultivated life is from necessaries to accommodations,

235. Id. at 29. It is hard to tell if the pun was intended. In any event, the First Circuit's emphasis on the fact-dependent nature of the appropriate judicial inquiry led it to insist-unlike the Court in Echazabal, discussed supra at note 192-that "a physician's endorsement does not provide complete insulation...." Id. at 31 .

236. Id. at 19.

237. Id. at 29 (quoting EEOC v. Prevo's Family Mkt., Inc., 135 F.3d 1089, 1097 (6th Cir. 1998)).

238. Ass'n for Disabled Ams. v. Concorde Gaming Corp., 158 F. Supp. $2 d 1353$ (S.D. Fla. 2001) (requiring bathroom access, but not access to gaming tables).

239. Access Now, Inc. v. South Fla. Stadium Corp., 161 F. Supp. 2d 1357 (S.D. Fla. 2001) (giving no right to additional special access tickets for sold-out professional sports event).

240. Kuketz v. MDC Fitness Corp., No. CA 9-0114-A, 2001 Mass. Super. LEXIS 347 (Aug. 17,2001) (upholding single bounce rule). 
from accommodations to ornaments. ${ }^{.241}$ In contrast to the Court's recent practice, I will not claim that a dictionary definition should be the basis for deciding vital public issues. But nondiscrimination and the new accommodations specifically recognized and guaranteed by the ADA constitute precisely the kinds of changes that are "fitting" and "suitable." They remain necessaries that can and should be worked out step-by-step over time.

Just as the basic attack on racial discrimination in the 1964 and 1965 Civil Rights Acts denoted progress for Americans of all races, the ADA's set of guarantees is actually vital to everyone. Discrimination may save money in the short run, of course, and it may be acceptable and even popular at times. But full and equal American citizenship demands a national guarantee of equal opportunity, equal access, and reasonable accommodation-even for those among us who may be different. By now, we ought to recognize that, at least in some contexts, formal evenhandedness will prove woefully inadequate to the task of affording real equality to different people.

We know that defining which cases actually are like cases, and then treating them alike, is a tricky, open-ended challenge. In our families, jobs, schools, and neighborhoods, moreover, we also recognize that basic fairness sometimes demands differential treatment. Throughout the ADA, Congress provided ways to take different human contexts into account, recognizing that the demands of equality cannot stop abruptly at some arbitrary threshold. Fundamentally, it appears that the current Court simply does not like the messiness of adjustments that are neither "either" nor "or." Despite the hostility of the Justices, however, case-by-case progress accommodating the basic rights of people who have faced, and still face, significant discrimination is more than proper. It remains within the essential public interest of us all. In fact and in context, our general welfare demands no less.

241. OXFORD ENGLISH DICTIONARY 58-59 (Compact ed., 1971). 